\title{
Sensitivity of the surface energy budget to drifting snow as simulated by MAR in coastal Adelie Land, Antarctica
}

\author{
Louis Le Toumelin ${ }^{1,2}$, Charles Amory ${ }^{1,3}$, Vincent Favier ${ }^{1}$, Christoph Kittel ${ }^{3}$, Stefan Hofer $^{4}$, Xavier Fettweis ${ }^{3}$, \\ Hubert Gallée ${ }^{1}$, and Vinay Kayetha ${ }^{5}$ \\ ${ }^{1}$ Université Grenoble Alpes, CNRS, Institut des Géosciences de l'Environnement, 38000 Grenoble, France \\ ${ }^{2}$ Univ. Grenoble Alpes, Université de Toulouse, Météo-France, CNRS, CNRM, \\ Centre d'Études de la Neige, Grenoble, France \\ ${ }^{3}$ F.R.S.-FNRS, Laboratory of Climatology, Department of Geography, University of Liège, 4000 Liège, Belgium \\ ${ }^{4}$ Department of Geosciences, University of Oslo, Oslo, Norway \\ ${ }^{5}$ Science Systems and Applications, Greenbelt, MD, USA
}

Correspondence: Louis Le Toumelin (louis.letoumelin@gmail.com)

Received: 3 November 2020 - Discussion started: 19 November 2020

Revised: 19 May 2021 - Accepted: 11 June 2021 - Published: 3 August 2021

\begin{abstract}
In order to understand the evolution of the climate of Antarctica, dominant processes that control surface and low-atmosphere meteorology need to be accurately captured in climate models. We used the regional climate model MAR (v3.11) at $10 \mathrm{~km}$ horizontal resolution, forced by ERA5 reanalysis over a 9-year period (2010-2018) to study the impact of drifting snow (designating here the wind-driven transport of snow particles below and above $2 \mathrm{~m}$ ) on the nearsurface atmosphere and surface in Adelie Land, East Antarctica. Two model runs were performed, one with and one without drifting snow, and compared to half-hourly in situ observations at D17, a coastal and windy location of Adelie Land. We show that sublimation of drifting-snow particles in the atmosphere drives the difference between model runs and is responsible for significant impacts on the near-surface atmosphere. By cooling the low atmosphere and increasing its relative humidity, drifting snow also reduces sensible and latent heat exchanges at the surface $\left(-5.7 \mathrm{~W} \mathrm{~m}^{-2}\right.$ on average). Moreover, large and dense drifting-snow layers act as near-surface cloud by interacting with incoming radiative fluxes, enhancing incoming longwave radiation and reducing incoming shortwave radiation in summer (net radiative forcing: $5.7 \mathrm{~W} \mathrm{~m}^{-2}$ ). Even if drifting snow modifies these processes involved in surface-atmosphere interactions, the total surface energy budget is only slightly modified by introducing drifting snow because of compensating effects in surface energy fluxes. The drifting-snow driven effects are
\end{abstract}

not prominent near the surface but peak higher in the boundary layer (fourth vertical level, $12 \mathrm{~m}$ ) where drifting-snow sublimation is the most pronounced. Accounting for drifting snow in MAR generally improves the comparison at D17, especially for the representation of relative humidity (mean bias reduced from $-14.0 \%$ to $-0.7 \%$ ) and incoming longwave radiation (mean bias reduced from $-20.4 \mathrm{~W} \mathrm{~m}^{-2}$ to $-14.9 \mathrm{~W} \mathrm{~m}^{-2}$ ). Consequently, our results suggest that a detailed representation of drifting-snow processes is required in climate models to better capture the near-surface meteorology and surface-atmosphere interactions in coastal Adelie Land.

\section{Introduction}

In order to improve estimates of the contribution of the Antarctic ice sheet to sea level rise in a global warming scenario (Edwards et al., 2019; Shepherd et al., 2018), an accurate representation of the current surface mass balance (SMB) of the ice sheet and overlying atmospheric physics in models is necessary (Agosta et al., 2019; van Wessem et al., 2018). A particular feature of the climate of Antarctica is the widespread, wind-driven removal and transport of snow, often referred to as drifting and blowing snow. Both processes are theoretically distinguished by the height of the wind-driven snow particles (below $2 \mathrm{~m}$ for drifting snow and 
above that height for blowing snow). For convenience, in our study drifting and blowing snow are combined into the single term of drifting snow.

Locally, drifting snow has proven itself to be a key SMB parameter. Even if drifting snow is subject to a high spatial and temporal variability, significant yearly frequency (up to $>90 \%$ of the time) and mass transport values have been reported at various places scattered over the Antarctic continent (e.g., Gossart et al., 2017; Mahesh et al., 2003; Mann et al., 2000; Scarchilli et al., 2010; Amory, 2020), especially in the megadune region and coastal windy regions (Palm et al., 2017, 2018). Over coastal locations, wind-driven ablation (erosion and sublimation of drifting-snow particles) and precipitation can be on the same order of magnitude (Scarchilli et al., 2010; van den Broeke et al., 2006). Drifting snow can spread horizontally over hundreds of kilometers and vertically over hundreds of meters (Palm et al., 2011) and remove by erosion all the accumulated firn at the surface, creating climate-sensitive low-albedo blue-ice areas (Bintanja, 1999; Favier et al., 2011; Scarchilli et al., 2010). On the scale of the Antarctic ice sheet, model studies even suggest that ablation may be primarily due to drifting snow (Lenaerts and van den Broeke, 2012; van Wessem et al., 2018; Palm et al., 2018), although drifting-snow mass transport could still be underestimated in regional model-based estimates of the Antarctic SMB (Agosta et al., 2019). Despite these efforts, driftingsnow processes still need to be more accurately resolved in models and better observationally constrained to improve our understanding of their influence on the climate and surface mass balance of Antarctica (Favier et al., 2017; Amory, 2020; Hanna et al., 2020).

Drifting-snow particles influence the local climate through their interactions with the lower atmosphere and the surface energy budget (SEB). Latent heat consumption and moisture released through sublimation of wind-driven particles modify the vertical gradients in temperature and humidity (e.g., Schmidt, 1982; Déry et al., 1998; Bintanja, 2000; Amory and Kittel, 2019), further affecting the turbulent heat exchange with the surface (Bintanja, 2001; Lenaerts and van den Broeke, 2012; Barral et al., 2014). Yang et al. (2014) observed through remotely sensed data that drifting snow can increase top-of-atmosphere outgoing longwave radiation by more than $20 \mathrm{~W} \mathrm{~m}^{-2}$ during wintertime in East Antarctica, suggesting a significant contribution of drifting snow to the atmospheric radiative budget. In the cold environment of central Antarctica, the lower atmosphere is usually very dry and clouds are generally optically thin (Mahesh et al., 2003; Town et al., 2007). The SEB is thus particularly sensitive to increases in the atmospheric longwave emissivity caused by additional suspended particles or water vapor due to driftingsnow sublimation. Yamanouchi and Kawaguchi (1984) highlighted increases in downwelling longwave radiation of up to $20 \mathrm{~W} \mathrm{~m}^{-2}$ below $30 \mathrm{~m}$ above ground during drifting snow from observations collected at Mizuho Station. The occurrence of drifting-snow layers has been linked to increases in surface temperature of typically a few degrees at the South Pole (Mahesh et al., 2003). In a modeling study with the regional climate model MAR, Gallée and Gorodetskaya (2010) showed that neglecting the contribution of suspended snow particles to the atmospheric longwave emissivity resulted in underestimation of the surface temperature at Dome C. Only small rises in surface temperature can be expected on the Antarctic plateau in response to additional drift-induced radiative forcing due to the strong surface-based temperature inversion that prevails throughout the year. But over coastal areas of the Antarctic ice sheet, which experience stronger wind speeds and related turbulent mixing and where higher, optically thicker drifting-snow layers can frequently develop (Palm et al., 2018), radiative effects of drifting snow currently remain poorly documented.

Drifting-snow data are extremely limited over highlatitude regions and still remain challenging to collect in the extreme and remote Antarctic environment (Amory, 2020). Drifting-snow effects are moreover directly embedded in measurable climate quantities and can hardly be disentangled from usual atmospheric measurements without accurate knowledge of drifting-snow properties in the whole atmospheric column. As an alternative, regional climate models provide continuous, high-resolution gridded estimates of individual climate components over large areas (van Wessem et al., 2018; Agosta et al., 2019). Detailed modeling may thus provide physical insights into the relevance and climatological significance of drifting snow. However, only a few regional models currently explicitly quantify drifting-snow processes (Lenaerts and van den Broeke, 2012; Gallée et al., 2013; Amory et al., 2015, 2021), and different implementation strategies from one model to another have been employed to account for interactions of drifting snow with the atmosphere (Gallée et al., 2013).

In this paper we use the regional climate model MAR to quantify the influence of drifting snow on the nearsurface climate and SEB in Adelie Land, a coastal region of East Antarctica particularly prone to erosive winds and where drifting-snow equipment deployed over the past few years provide observational support for model evaluation near the surface (Trouvilliez et al., 2014; Amory et al., 2021). MAR has been widely used to simulate the climate and surface mass balance of polar ice sheets (e.g., Fettweis et al., 2017, 2020; Hofer et al., 2017, 2019; Kittel et al., 2018, 2021; Mottram et al., 2020) and includes a detailed representation of drifting-snow processes already applied to study snow mass transport and wind-driven ablation in coastal East Antarctica (Gallée et al., 2005, 2013; Amory et al., 2015, 2021). The explicit coupling of the drifting-snow scheme with the atmospheric component of the model enables a vertical discretization of drifting-snow profiles and related sublimation within the atmospheric boundary layer and takes into account the radiative contribution of driftingsnow particles. 


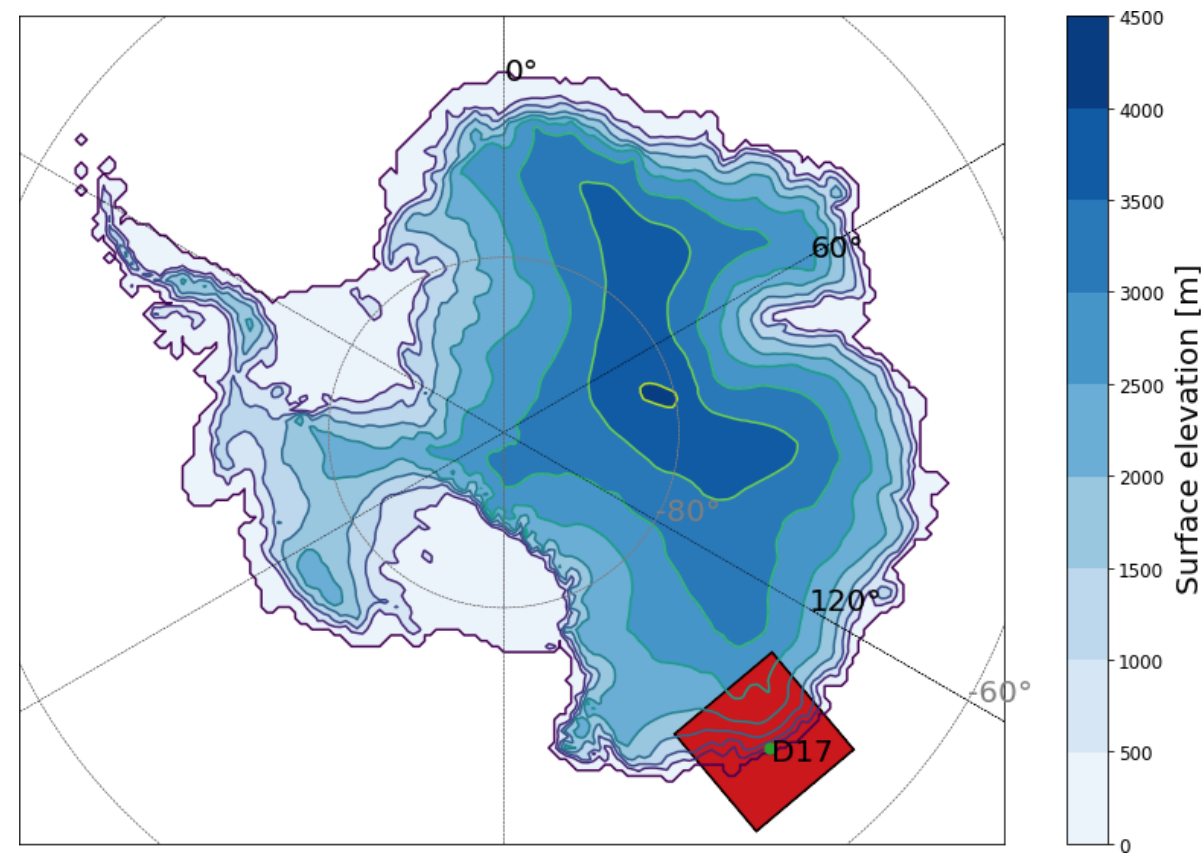

Figure 1. Antarctic topography as used in MAR. The integration domain over Adelie Land is displayed in red with a green dot for the location of D17.

The observations, model setup, and data processing methods are described in Sect. 2. The main modifications induced by drifting snow on the surface and near-surface meteorology at D17 are detailed in Sect. 3. Section 4 discusses the results including the impact of drifting snow on the boundary layer and their spatial distribution in Adelie Land. Finally, Sect. 5 summarizes and concludes the study.

\section{Methods and data}

\subsection{Field area and instrumentation}

Site D17 $\left(66.7^{\circ} \mathrm{S}, 139.9^{\circ} \mathrm{E} ; 450 \mathrm{~m}\right.$ above sea level; Fig. 1) is located $10 \mathrm{~km}$ inland and $15 \mathrm{~km}$ southwest of the permanent French station of Dumont d'Urville in Adelie Land, East Antarctica. The measurement area is characterized by strong and persistent katabatic winds mostly originating from the southeast direction and flowing over a permanent snow surface, favoring the regular occurrence of drifting snow (Amory, 2020).

A $7 \mathrm{~m}$ meteorological mast was installed at D17 in 2010 providing relative humidity, wind speed, and temperature measurements at six logarithmically spaced levels (nominal heights $0.8,1.3,2,2.8,3.9$, and $5.5 \mathrm{~m}$ above the surface). An ultrasonic depth gauge has measured changes in elevation above ground level (a.g.l.) since December 2012. Relative humidity is initially assessed with respect to liquid water, and the calculation necessary to convert raw values into relative humidity with respect to ice is performed according to
Goff and Gratch (1945). As supersaturation is very unlikely at this coastal location, notably due to frequent drifting snow, converted values exceeding $100 \%$ are attributed to limitation of the conversion method and capped to $100 \%$ (Barral et al., 2014).

Radiative fluxes designate the incoming shortwave radiation (SWD), outgoing shortwave radiation (SWU), incoming longwave radiation (LWD), and outgoing longwave radiation (LWU). All fluxes are defined positive when directed towards the surface. A Kipp and Zonen CNR4 net radiometer was installed in early February 2014 next to the meteorological mast (Amory et al., 2020b). This sensor is composed of two pairs of pyrgeometers and pyranometers: the first one measures SWD and SWU (spectral range: 300 to $2800 \mathrm{~nm}$ ) and the second one LWD and LWU (spectral range: 4500 to $42000 \mathrm{~nm}$ ). Sensor characteristics are presented in Table 1. Negative values of each radiation flux were set to 0 . Summer maintenance operations and winter excessive discharge of the station's battery between May and September 2018 impacted measurement continuity. The later period was characterized by a gap of $55 \%$ in the radiative flux observations. Outside of this last time frame, few observations are missing, as reported in Table 1.

Calculation of the turbulent heat fluxes, composed by the sensible heat flux (SHF) and the latent heat flux (LHF), could be possible with observations at D17 (relative humidity, temperature, and wind speed) through the application of the profile method (Barral et al., 2014). However, there is a concern about the applicability of Monin-Obukhov similarity theory in drifting-snow conditions, as the requirement of ver- 
Table 1. Observed variables and technical specifications for the sensors used at D17.

\begin{tabular}{|c|c|c|c|c|c|}
\hline Variable & Sensor & Manufacturer & Accuracy & Observation period & $\frac{\text { Number of unavailable data }}{\text { All time steps }}$ \\
\hline Wind speed & A100LK & Campbell Scientific & $1 \% \pm 0.1 \mathrm{~ms}-1$ & $2010-2018$ & $<1 \%$ \\
\hline Relative humidity & HMP45A & Vaisala & $\begin{array}{l}3 \% \text { for } \mathrm{RH}>90 \% \\
2 \% \text { for } \mathrm{RH}<90 \%\end{array}$ & $2010-2018$ & $<1 \%$ \\
\hline Temperature & HMP45A & Vaisala & $\pm 0.4^{\circ} \mathrm{C}$ & 2010-2018 & $<1 \%$ \\
\hline Snow height & $\begin{array}{l}\text { Acoustic depth } \\
\text { gauge SR50 }\end{array}$ & Campbell Scientific & $\pm 0.01 \mathrm{~m}$ & 2013-2018 & $<1 \%$ \\
\hline $\begin{array}{l}\text { Drifting-snow } \\
\text { flux }\end{array}$ & 2G-FlowCapt ${ }^{\mathrm{TM}}$ & IAV Engineering & Not specified & $2013-2018$ & $<1 \%$ \\
\hline Radiation & CNR4 & Kipp and Zonen & $5 \%$ in daily totals & Feb. 2014-2018 & $6 \%$ \\
\hline
\end{tabular}

tical constancy in turbulent fluxes is not met (Bintanja, 2001; Amory and Kittel, 2019). Moreover, during drifting-snow occurrences, turbulent mixing and atmospheric sublimation favor the establishment of near-surface atmospheric layers characterized by low vertical gradients in humidity and temperature. Those gradients are frequently lower than the sensor accuracies, leading to large uncertainties in the derived turbulent fluxes. Barral et al. (2014) observed amplified uncertainty with strong winds at D17, further limiting the use of the profile method during drifting-snow conditions. The same conclusion is drawn here, as determination of turbulent fluxes was intended but led to strongly diverging results according to the choice of the method (bulk vs. profile method), the stability function, and the number and considered height a.g.l. of the measurement levels (not shown). Thus, no observed turbulent fluxes are available here for model evaluation.

Information on drifting snow is obtained using secondgeneration IAV engineering FlowCapt sensors (hereafter referred to as 2G-FlowCapt ${ }^{\mathrm{TM}}$; Amory et al., 2020a). The 2GFlowCapt ${ }^{\mathrm{TM}}$ is a $1 \mathrm{~m}$ long tube, containing an electroacoustic transducer measuring the noise generated by the impact of drifting-snow particles on the tube. The signal is then converted into a drifting-snow flux integrated over the exposed length of the tube. At D17, a pair of 2G-FlowCapt ${ }^{\mathrm{TM}}$ instruments has been operational since late December 2012. The sensors are set up vertically one above the other starting from the ground. This configuration enables the detection of the initiation of drifting snow and measurement of the driftingsnow flux near the surface $(\leq 2 \mathrm{~m})$.

While the 2G-FlowCapt ${ }^{\mathrm{TM}}$ has been shown to underestimate drifting-snow fluxes compared to optical measurements in the French Alps (Trouvilliez et al., 2015), its behavior still needs to be assessed in the extreme Antarctic environment where different climatic conditions and particle properties influencing the measurement can be expected (Cierco et al., 2007). A preliminary evaluation of the $2 \mathrm{G}-$ FlowCapt ${ }^{\mathrm{TM}}$ instrument against optical measurements was performed at
D17 during one drifting-snow event and shows good agreement between both types of sensors (Amory, 2020). The lowest 2G-FlowCapt ${ }^{\mathrm{TM}}$ (respectively, the highest) of exposed length $h_{1}$ (respectively, $h_{2}$ ) measures a drifting-snow flux designated as $\mathrm{FC}_{1}$ (respectively, $\mathrm{FC}_{2}$ ). Equation (1) expresses the mean drifting-snow flux FC and takes into account the measurement height, as accumulation can partially bury the lower $2 \mathrm{G}-\mathrm{FlowCapt}^{\mathrm{TM}}$ :

$\mathrm{FC}=\frac{h_{1} \cdot \mathrm{FC}_{1}+h_{2} \cdot \mathrm{FC}_{2}}{h_{1}+h_{2}}$.

All measurements are recorded every $15 \mathrm{~s}$ and mean values are performed every $30 \mathrm{~min}$ and stored on a Campbell CR3000 data logger.

\subsection{Model description}

MAR is a hydrostatic regional climate model solving primitive equations as originally described in Gallée and Schayes (1994) and has been extensively used for decade-long climate simulations over high-latitude regions (e.g., Agosta et al., 2019; Fettweis et al., 2017, 2020; Mottram et al., 2020; Kittel et al., 2021). Five atmospheric water species are represented in the model: specific humidity, cloud droplets, rain drops, cloud ice crystals, and snow particles (Gallée and Schayes, 1994). Radiative transfer through the atmosphere is calculated according to Morcrette (2002), and cloud radiative properties are calculated according to Ebert and Curry (1992) based on water species concentrations. MAR is coupled to the surface scheme SISVAT (soil-ice-snow-vegetationatmosphere transfer; Gallée and Duynkerke, 1997; De Ridder and Gallée, 1998; Gallée et al., 2001), which handles energy and mass transfer between the atmosphere and the surface, and includes a multi-layer snow and ice model representing snow properties (dendricity, sphericity, and size) taken from an early version of the CROCUS snow model (Brun et al., 1992). Surface sublimation (which is distinguished in the model from atmospheric sublimation) and latent heat ex- 
changes at the surface are computed following a bulk flux formulation in SISVAT.

MAR includes a drifting-snow scheme originally described in Gallée et al. (2001). A detailed description of its latest version (including updates, changes relative to the original version, and interactions with the surface and the atmosphere) can be found in Amory et al. (2021). In brief, the drifting-snow scheme simulates erosion at every grid cell in which the modeled friction velocity, $u_{*}$, exceeds a threshold value, $u_{* t}$, depending on the local surface snow density. While former parameterizations of $u_{* t}$ in the model did involve other snow microstructural properties such as snow grain shape and size (Gallée et al., 2001), for which observations are virtually non-existent in Antarctica, here the formulation for $u_{* t}$ has been simplified and sensitivity parameters have been reduced to surface snow density only, a variable better observationally constrained (Amory et al., 2021). Once removed from the snowpack, eroded snow is mixed with the pre-existing wind-borne snow mass and advected to higher atmospheric levels and/or downwind grid cells by the turbulence and microphysical schemes. Interactions with the atmosphere are computed by the microphysical and the radiative transfer schemes. In particular, atmospheric sublimation (including both cloud-originating particles and drifting-snow particles) is computed by the model microphysics (Gallée, 1995). This formulation is based on the assumption of an exponential distribution for particle size $n_{\mathrm{s}}$ (Eq. 2):

$n_{\mathrm{s}}=n_{0} \exp \left(-\lambda_{\mathrm{s}} D_{\mathrm{s}}\right)$

where $n_{0}$ is a constant representing the intercept parameter of the distribution. $n_{0}$ is empirically determined and was set to $3 \times 10^{8} \mathrm{~m}^{-4}$ in our study. $D_{\mathrm{s}}$ corresponds to the particle diameter (expressed in $\mathrm{m}$ ) and $\lambda_{\mathrm{s}}$ the dispersion parameter (expressed in $\mathrm{m}^{-1}$ ). $\lambda_{\mathrm{s}}$ is determined as follows (Eq. 3):

$\lambda_{\mathrm{s}}=\left(\frac{\pi \rho n_{0}}{\rho_{\mathrm{a}} q_{\mathrm{s}}}\right)^{1 / 4}$,

where $\rho$ is the snow particle density $\left(100 \mathrm{~kg} \mathrm{~m}^{-3}\right), \rho_{\mathrm{a}}$ is the air density $\left(\mathrm{kg} \mathrm{m}^{-3}\right)$, and $q_{\mathrm{s}}$ the snow particle ratio (expressed in kilograms of snow per kilogram of air). Sublimation is then computed as a function of the air temperature, snow particle ratio, and relative humidity so that sublimation only occurs in a subsaturated environment with respect to ice (Eq. 31 in Lin et al., 1983; p. 1072). It also considers snow particles as graupel-like snow of hexagonal type (Locatelli and Hobbs, 1974). Consequently, drifting-snow sublimation modifies the local humidity budget, the lower atmosphere stratification, and moist air advection. Representing the contribution of drifting-snow layers to the atmospheric radiative forcing is accounted for in MAR by including suspended snow particles in the computation of cloud radiative properties (Gallée and Gorodetskaya, 2010). Ultimately, the momentum balance of the boundary layer is mainly affected through three distinct processes when accounting for drifting snow in MAR. Firstly, the increase in air density due to the weight of suspended snow, which is accounted for in the model by including the contribution of suspended snow in the computation of the potential virtual temperature (Gallée et al., 2001), is inherently amplified when eroded particles contribute to the airborne snow mass. Secondly, driftingsnow sublimation and subsequent cooling of the atmosphere is computed at each model vertical level and contributes to increasing air density and atmospheric stability, which enhances the along-slope pressure gradient force and is a positive feedback in katabatic flows (Kodama et al., 1985; Gallée, 1998). Finally, the aerodynamic roughness length $z_{0}$ is computed following a relationship previously fitted on observed $z_{0}$ values in order to take into account the seasonality of surface roughness in a drifting-snow climate as observed in Adelie Land (Amory et al., 2021). More precisely, $z_{0}$ is computed as a function of air temperature (for temperatures above $-20^{\circ} \mathrm{C}$ ) and set to a constant value of $2 \times 10^{-4} \mathrm{~m}$ representative of inland conditions (Vignon et al., 2017) for temperatures below $-20^{\circ} \mathrm{C}$.

We used the latest model version MARv3.11 (hereafter referred to as MAR) and setup as presented in Amory et al. (2021), in which the model is run with a horizontal resolution of $10 \mathrm{~km}$ over a domain of $80 \times 80$ grid cells centered on the location of D17. The atmosphere is described with 24 levels in the vertical, with a higher vertical resolution in the low troposphere. The lowest level is situated at $2 \mathrm{~m}$ a.g.l. Top-of-atmosphere and lateral forcing plus sea surface conditions are taken from 6-hourly ERA5 reanalysis (Hersbach et al., 2020). ERA5 products evaluated in Antarctica (e.g., Gossart et al., 2017) notably assimilate radiosoundings operated every day at the nearby permanent station Dumont D'Urville, favoring a consistency between ERA5 and the observed climate in Adelie Land. The two models runs were performed with MAR over the 2010-2018 period. In the first run (referred to as MAR-DR), the drifting-snow scheme was activated oppositely to the second run (referred to as MARnDR).

\subsection{Using CALIPSO to calculate drifting snow height in MAR}

Estimates of drifting-snow layer heights in MAR-DR are calibrated on CALIPSO observations. We underline the fact that satellite products are not used here for model evaluation but rather as an independent product from which an objective criterion can be used to infer drifting-snow layer heights in our MAR simulations.

Palm et al. (2011) developed a remotely sensed technique to detect drifting-snow properties and particularly the drifting-snow layer height. Lidar backscattered signal interaction with drifting snow is studied using the CloudAerosol Lidar and Infrared Pathfinder Satellite Observations (CALIPSO) satellite. Under clear-sky conditions, an algo- 
rithm extensively detailed in Palm et al. (2011) analyzes the CALIPSO lidar attenuated backscatter signal over Antarctica and determines elevations of a scattering layer representative of the top of a drifting-snow layer. Such estimates enable drifting-snow detection for layers higher than $30 \mathrm{~m}$. However, the snow particle ratio (which equals the mass of snow particles per kilogram of air, including dry air, humidity, and the mass of all other hydrometeors) at the top of the driftingsnow layer, is not known.

The calibration algorithm works as follows. We firstly studied CALIPSO swaths above a 1 by 1 degree box centered on D17. When the satellite swath covers this box and both MAR and the CALIPSO detection algorithm indicate a drifting-snow occurrence, the remotely sensed drifting-snow layer height is retrieved. Then, the snow particle ratio (the mass of snow particles per kilogram of air at each model vertical level) from the closest vertical level in the MARDR simulation is stored (referred to as $q_{s 0}$ ). Between January 2010 and October 2017, CALIPSO detected 56 distinct drifting-snow occurrences among the 462 observations available in the D17 area, giving $q_{s}$ values among which a mean snow particle ratio $\overline{q_{s 0}}$ is computed. $\overline{q_{s 0}}$, referred to as the CALIPSO snow particle ratio threshold, is representative of the snow concentration required for the satellite to detect a drifting-snow layer. Secondly, all MAR-DR simulations are selected when the drifting snow is simulated (i.e., when the drifting-snow flux at the lowest model level $>10^{-3} \mathrm{~kg} \mathrm{~m}^{2} \mathrm{~s}^{-1}$, calculated according to Amory et al., 2015). The highest vertical level with a snow particle ratio above $\overline{q_{s 0}}$ corresponds to the drifting-snow layer height. In order to avoid accounting for modeled advected precipitation or atmospheric clouds as drifting-snow layers, data were filtered according to the method described in Sect. 2.4. The model vertical discretization sets limits to the estimation of drifting-snow layer heights that are necessarily underestimated in MAR-DR if we consider CALIPSO-detected heights as a reference (drifting-snow height distributions are proposed in Fig. S5 in the Supplement).

\subsection{Data filtering}

When drifting snow occurs, MAR computes radiative modifications related to both the presence of drifting-snow particles and the changes in the cloud representation. In Sect. 3.3, we focus on the radiative contribution of snow particles resulting from the erosion of the surface only, a task that is required to filter the data.

Firstly, because cloud formation might be influenced by drifting snow through atmospheric sublimation and changes in the amount and distribution of atmospheric water species, it may induce radiative effects that are not directly related to drifting-snow particles. The question of the role of drifting snow on cloud formation cannot be supported here by enough observations and requires further investigations. Thus, we rejected all the cases where the increase in concentrations of cloud droplets, rain, and ice crystals were among the $10 \%$ highest increases between MAR-DR and MAR-nDR simulations.

Secondly, snowfall occurrence must be removed. Precipitating particles during snowfall can be distinguished between particles reaching the ground (designated as snowfall ground) and particles sublimating entirely during their falling through the atmosphere (designated as snowfall ${ }_{\text {virga }}$ ). As MAR-DR mixes snowfall ${ }_{\text {ground }}$, snowfall $l_{\text {virga }}$, and eroded snow particles in the snow particle ratio, we use the MAR-nDR simulation to discard snowfall ground and snowfall virga $_{\text {occur- }}$ rences from both simulations. Once snowfall ground cases in MAR-nDR have been excluded, snowfall ${ }_{\text {virga }}$ were identified from the remaining cases in MAR-nDR (i.e., without snowfall ground) as all profiles with a snow particle ratio above $q_{\text {snow0.9 }}$ at any vertical level. $q_{\text {snow0.9 }}$ is the 0.9 quantile of the snow particle ratio at the lowest vertical level. As a consequence, we rejected many snowfall occurrences, including drifting snow mixed with snowfall occurrences and more generally many cloudy periods. Few single clear outliers remain after the filtering process (drifting-snow layer height $>2000 \mathrm{~m}$ ) and are discarded.

Finally 16699 simulated atmospheric profiles were available for analysis. Those profiles, designated as "filtered conditions", hold valuable information about the direct radiative contribution of eroded snow particles without interfering with the radiative contribution of snowfall or newly formed atmospheric water species.

\section{Results}

The ability of MAR to reproduce the drifting-snow climate of Adelie Land has been extensively evaluated in Amory et al. (2021), in which a close agreement with observations is demonstrated for the SMB, drifting-snow mass transport, and frequency up to the scale of the drifting-snow event. We refer to this study for further details on the model evaluation regarding drifting snow. In this section, we focus on the impact of drifting snow on the representation of surface and near-surface meteorological variables. This is achieved by comparing two sets of simulations in which the driftingsnow scheme has been, respectively, switched on (referred to as MAR-DR) and off (referred to as MAR-nDR). The results are compared over periods for which observations are also available, i.e., 2010-2018 for near-surface wind speed, air temperature, and relative humidity and 2014-2018 for radiative fluxes. Except for the surface turbulent fluxes, all other meteorological variables are observed at D17. Half-hourly variables extracted from the surface or the lowest model level $(2 \mathrm{~m})$ and the nearest grid cell to the observation location are used for comparison. Modifications of near-surface and surface variables are summarized in a Taylor diagram (Taylor, 2001) presented in the Supplement (Fig. S1). 

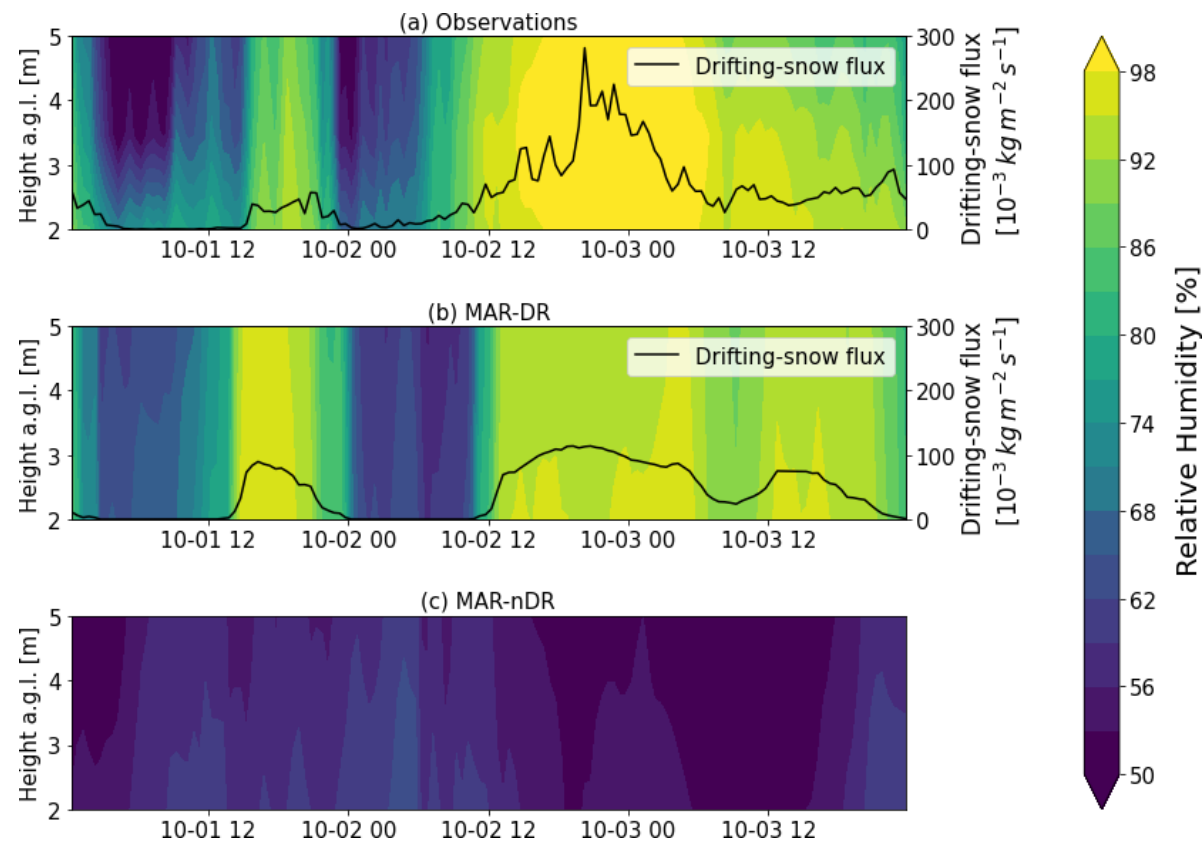

Figure 2. (a) Observed, (b) MAR-DR, and (c) MAR-nDR vertical relative humidity profile (with respect to ice; color) and drifting-snow fluxes (from the surface to $2 \mathrm{~m}$ a.g.l.; black line) between 1 and 3 October 2017.

\subsection{A case study}

We firstly focus on a strong drifting-snow event that occurred over the 1-3 October 2017 period at D17 to understand the physical processes involved in important changes between MAR-DR and MAR-nDR simulations.

\subsubsection{Relative humidity, temperature, and wind speed}

MAR-DR captures the drifting-snow event in terms of timing and occurrence but underestimates the magnitude of the drifting-snow flux. The simulated drifting-snow flux is approximately 3 times lower than the observed flux at the peak of the event. The near-surface humidity budget is particularly impacted during this specific event (Fig. 2). When drifting snow occurs, a near-saturated layer develops in the lowest meters of the atmosphere. During the peak of the event, this layer reaches saturation. MAR-DR reproduces this observed increase in relative humidity, while relative humidity from the MAR-nDR simulation is lower by up to $47 \%$.

As no snowfall is simulated during this event, the high snow particle ratio found in the lower part of the driftingsnow layer can be largely attributed to snow eroded from the surface by the wind (Fig. 3a). Once suspended in the atmosphere, those particles sublimate in proportion to the undersaturation of ambient air (Schmidt, 1982) (Fig. 3b), and relative humidity increases due to moisture release and consumption of latent heat and subsequent cooling of the atmosphere. This cooling decreases the $2 \mathrm{~m}$ temperatures (Fig. 3f) and also reduces the positive temperature bias in compari- son to in situ observations. Wind speeds increase in MARDR compared to MAR-nDR (Fig. 3h), which are discussed in more detail in Sect. 4.1. Figure S6 illustrates the impact of drifting snow on vertical profiles of temperature, relative humidity, and wind speed in the model at D17 during this event.

\subsubsection{Incoming radiative fluxes, turbulent fluxes, and surface energy budget}

During the 1-3 October 2017 period, both radiative and turbulent fluxes at the surface were modified by drifting snow. On one hand, in MAR-DR during modeled drifting-snow occurrences, the net longwave radiation (LWnet), defined as LWD + LWU and calculated at each model vertical level, increases close to the surface and peaks where the snow particle ratio is maximum (Fig. 3c). Conversely, the net shortwave radiation (SWnet), defined as SWD+SWU, decreases (Fig. 3d). Those modifications are transferred towards the surface where large differences in LWD and SWD between MAR-DR and MAR-nDR are visible (Fig. 3k, 1), suggesting the drifting-snow layer acts as a near-surface cloud by enhancing LWD and decreasing SWD at the surface. Yamanouchi and Kawaguchi (1984) observed similar LWD and SWD variations over the first $30 \mathrm{~m}$ of the atmosphere at Mizuho station during drifting-snow episodes.

On the other hand, surface turbulent fluxes (not observed; see Sect. 2.1) is reduced when drifting snow is considered in the model (Fig. 3i, j). The development of a near-saturated layer over the first meters of the atmosphere due to drifting- 

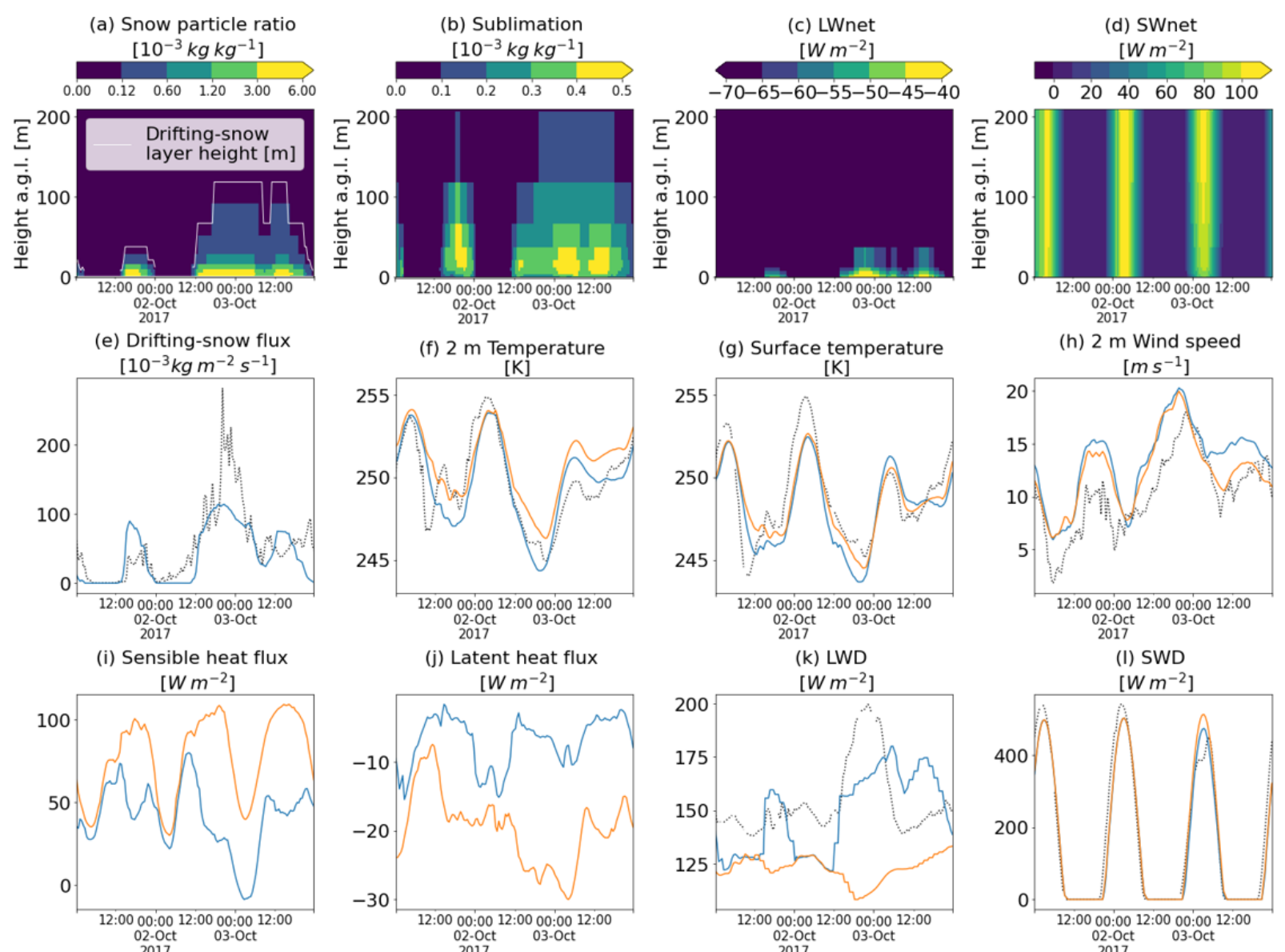

(g) Surface temperature

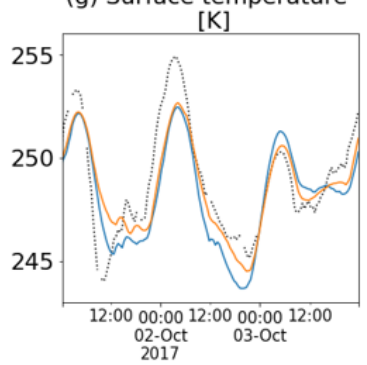

(h) $2 \mathrm{~m}$ Wind speed

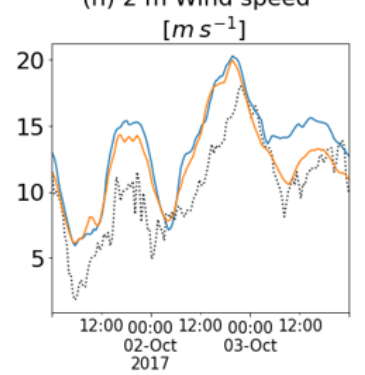

(j) Latent heat flux $\left[\mathrm{Wm}^{-2}\right]$

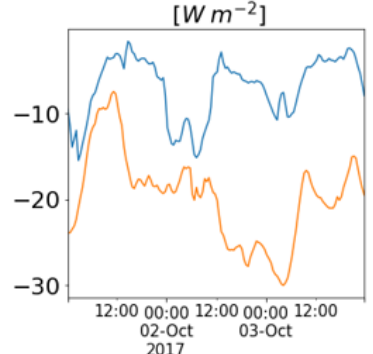

(k) LWD

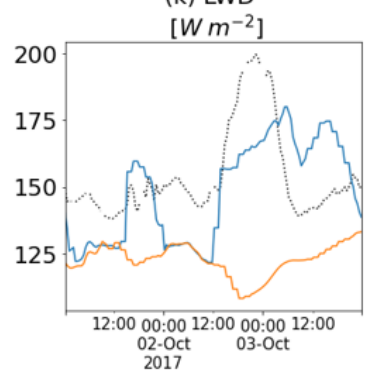

(I) SWD

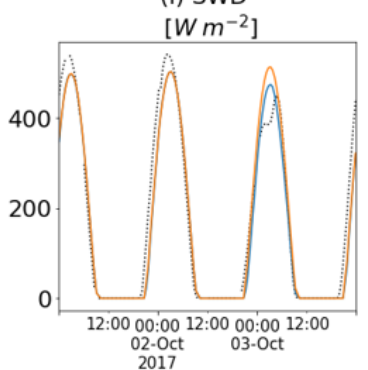

(m) LWnet + SWnet + LHF + SHF
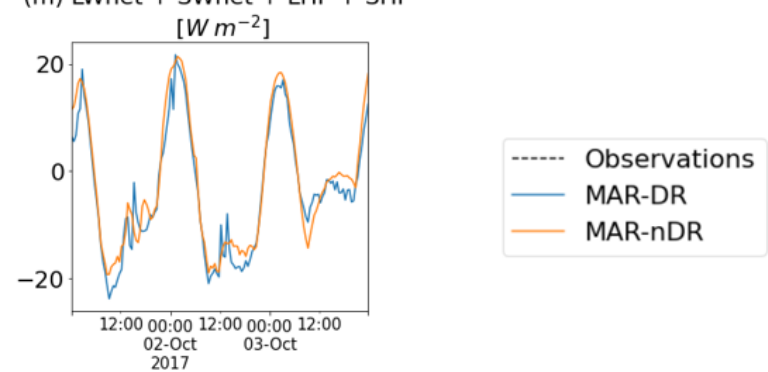

Figure 3. (a) Snow particle ratio, (b) sublimation (expressed in grams of sublimated snow per kilogram of moist air per 30 min), (c) SWnet, and (d) LWnet vertical profiles as simulated by MAR-DR during a drifting-snow episode occurring between 1 and 3 October 2017. (e)(m) $2 \mathrm{~m}$ and surface variables as observed and simulated by MAR-DR and MAR-nDR between 1 and 3 October 2017.

snow sublimation (Fig. 2) reduces the humidity gradient and prevents surface sublimation with less latent heat exchange at the surface. Furthermore, atmospheric sublimation cools the atmosphere, inducing reduced vertical temperature gradients and lower sensible heat fluxes at the surface.

In summary, we find that drifting snow induces an increase in net radiative fluxes $\left(+22.5 \mathrm{~W} \mathrm{~m}^{-2}\right.$ on average during the considered period), which is driven by increasing LWD and decreasing SWD. This compensates for modifications in turbulent fluxes $\left(-24.06 \mathrm{~W} \mathrm{~m}^{-2}\right)$. Consequently, our simulations suggest that notable impacts on the energy inputs result in a negligible change in the final energy budget and surface temperature during this specific period.

\subsection{Seasonal modifications}

Drifting snow not only impacts the near-surface meteorology during specific events, but it also modifies their seasonal cycle at D17 (Fig. 4). As drifting snow becomes more frequent in winter (March-October) in Adelie Land due to the increased katabatic forcing (Amory, 2020), its related impacts on the lower atmosphere are most notable during that period. 
(a) 2 m Relative humidity [\%]

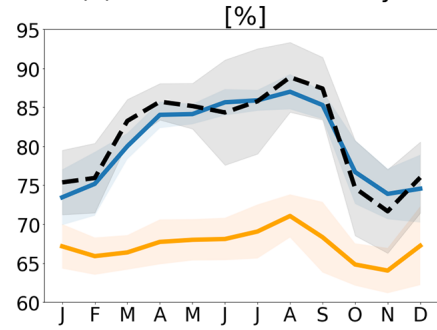

(d) Surface temperature $[\mathrm{K}]$

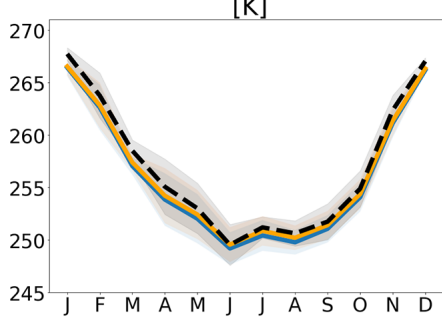

(g) SWD

$\left[W^{-2}\right]$

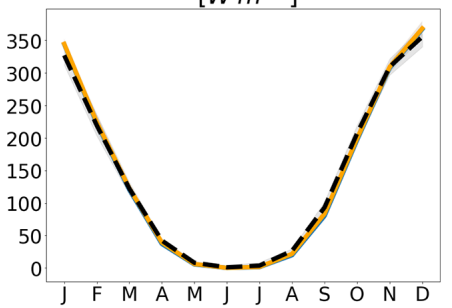

(j) SHF

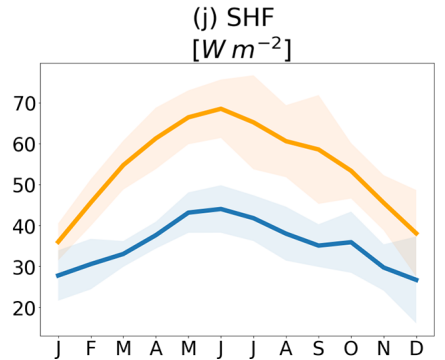

(b) $2 \mathrm{~m}$ Wind speed $\left[m s^{-1}\right]$

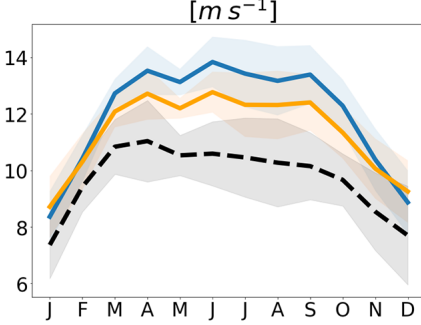

(e) LWD

[W $\mathrm{m}^{-2}$ ]

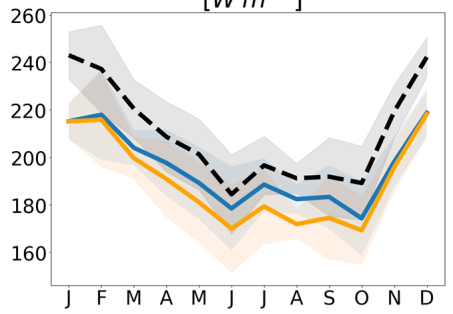

(h) SWU

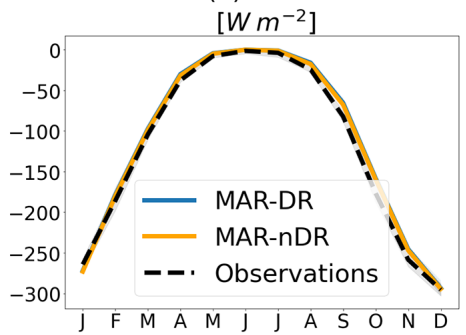

(k) LWnet + SWnet + LHF + SHF

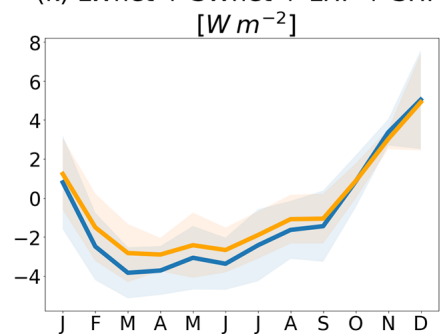

(c) $2 \mathrm{~m}$ Temperature

[K]

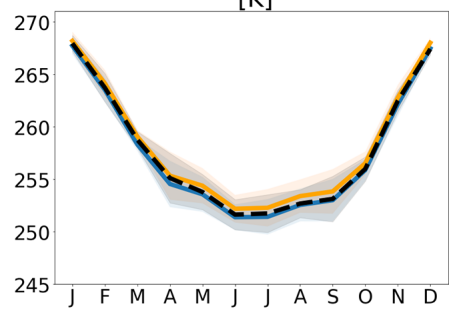

(f) LWU
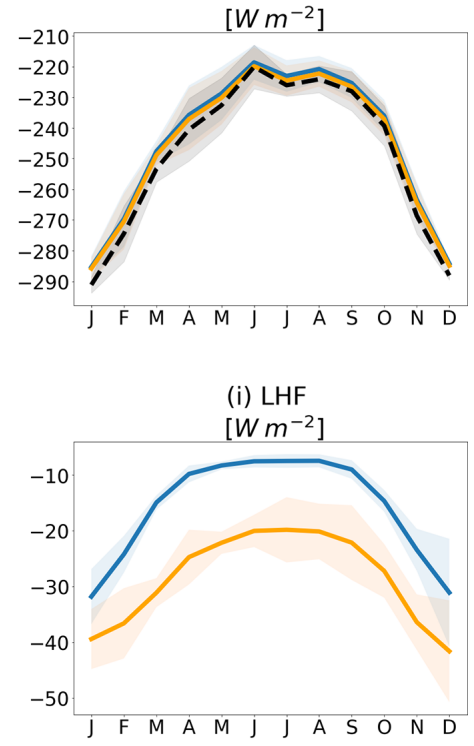

(i) $\mathrm{LHF}$

$$
\text { (a) }
$$


Table 2. Root mean square error (RMSE), Pearson correlation coefficient, and mean bias computed at D17 for MAR-DR and MAR-nDR half-hourly simulations in comparison with in situ observations.

\begin{tabular}{|c|c|c|c|c|c|c|}
\hline & \multicolumn{2}{|c|}{$r$} & \multicolumn{2}{|c|}{ RMSE } & \multicolumn{2}{|c|}{ Mean bias } \\
\hline & MAR-DR & MAR-nDR & MAR-DR & MAR-nDR & MAR-DR & MAR-nDR \\
\hline $\operatorname{LWD}\left(\mathrm{W} \mathrm{m}^{-2}\right)$ & 0.87 & 0.89 & 19.9 & 22.8 & -14.9 & -20.4 \\
\hline $\operatorname{LWU}\left(\mathrm{W} \mathrm{m}^{-2}\right)$ & 0.97 & 0.98 & 6.5 & 5.6 & -4.0 & -2.9 \\
\hline $\operatorname{SWD}\left(\mathrm{W} \mathrm{m}^{-2}\right)$ & 0.98 & 0.98 & 24.6 & 24.2 & -1.3 & 0.3 \\
\hline $\operatorname{SWU}\left(\mathrm{W} \mathrm{m}^{-2}\right)$ & 0.98 & 0.98 & 22.4 & 22.0 & -7.0 & -5.9 \\
\hline Surface temperature (K) & 0.97 & 0.98 & 1.7 & 1.4 & -1.0 & -0.7 \\
\hline $2 \mathrm{~m}$ temperature $(\mathrm{K})$ & 0.97 & 0.98 & 1.3 & 1.2 & -0.2 & 0.5 \\
\hline $2 \mathrm{~m}$ wind speed $\left(\mathrm{m} \mathrm{s}^{-1}\right)$ & 0.78 & 0.82 & 3.0 & 2.5 & 2.3 & 1.7 \\
\hline $2 \mathrm{~m}$ relative humidity $(\%)$ & 0.62 & 0.51 & 9.5 & 15.8 & -0.7 & -14.0 \\
\hline
\end{tabular}

(Table 2), suggesting that drifting-snow sublimation mainly governs temporal variations in relative humidity at D17 in agreement with Amory and Kittel (2019).

Drifting snow also accounts for lower $2 \mathrm{~m}$ temperatures in MAR-DR at D17 ( $-0.7 \mathrm{~K}$ on average), particularly during winter (Fig. 4c). However, further analysis shows that the most important temperature modifications occur higher up in the drifting-snow layer (Sect. 4.1). Accounting for drifting snow in MAR reduces the $2 \mathrm{~m}$ temperature positive bias in comparison with observations (divided by a factor 2.5; Table 2).

\subsubsection{Incoming radiative fluxes, turbulent fluxes, and surface energy budget}

Drifting snow enhances the seasonal values of LWD (Fig. 4e), but even if significant modifications in SWD can occur during specific events such as those presented in Fig. 3d, the impact on seasonal averages is low (Fig. 4g). LWD are mainly modified during winter, in pace with the seasonal cycle of drifting snow. LWD modifications are even more visible during this period because atmospheric temperatures reach their minimum. As MAR-nDR underestimated LWD at D17 (the mean bias equals $-20.4 \mathrm{~W} \mathrm{~m}^{-2}$ ), the LWD negative bias is reduced to $-14.9 \mathrm{~W} \mathrm{~m}^{-2}$ in MAR-DR, showing that the latter simulates more realistic LWD values in winter. The impact of drifting snow on other incoming and outgoing radiative fluxes at the surface is lower (Table 2).

Drifting snow accounts for a significant decrease in SHF and LHF, i.e., larger than the interannual variability (taken as the standard deviation computed from annual means) during the 2010-2018 period. By increasing relative humidity in the lower atmosphere (Fig. 4a), drifting-snow sublimation decreases the vertical gradient in humidity and limits latent heat exchanges with the surface. As a consequence, surface sublimation is locally reduced by a factor of 2.0 in MAR-DR (LHF, expressed in $\mathrm{W} \mathrm{m}^{-2}$; Fig. 4i). However, at the same time, drifting-snow sublimation cools the boundary layer, reduces vertical temperature gradients, and coun- terbalances the decrease in LHF by a decrease in SHF (SHF divided by a factor 1.9 at D17; Fig. 4 j).

Overall, drifting snow shows very little impact on the energy budget $\left(\mathrm{LWnet}+\mathrm{SWnet}+\mathrm{LHF}+\mathrm{SHF}=-0.5 \mathrm{~W} \mathrm{~m}^{-2}\right) . \quad$ This results from a compensation between the net driftingsnow radiative forcing (difference in SWnet + LWnet between simulations $=6.1 \mathrm{~W} \mathrm{~m}^{-2}$ ) and the surface turbulent heat fluxes (difference in LHF + SHF between simulations $=-6.6 \mathrm{~W} \mathrm{~m}^{-2}$ ). As the energy available at the surface has not been notably modified by introducing drifting snow in MAR-DR, the surface temperature is almost unchanged ( $-0.3 \mathrm{~K}$; Fig. 4 d).

\subsection{Impact on incoming radiation}

In this section, the impact of drifting snow on incoming radiation is analyzed. In order to more specifically focus on the radiative contribution of eroded snow particles in MAR-DR, we filtered data according to Sect. 2.4. Thus, we discarded cases with snowfall or modifications in the cloud structure between MAR-DR and MAR-nDR.

We observed that under such conditions, LWD modifications correlate linearly with the drifting-snow flux. Conversely, when significant SWD reaches the surface $\left(>50 \mathrm{~W} \mathrm{~m}^{-2}\right)$, SWD decreases linearly with the driftingsnow flux (Fig. 5a, c). Furthermore, large modifications in incoming radiative fluxes are associated with thick and dense drifting-snow layers (Fig. 5b, d).

According to Fig. 5, the most significant drifting-snow events (drifting-snow fluxes $>=75 \times 10^{-3} \mathrm{~kg} \mathrm{~m}^{2} \mathrm{~s}^{-1}$ and layer height $>100 \mathrm{~m}$ ) can lead to large increases in LWD; the largest increase occurs in June 2013 with $+72 \mathrm{~W} \mathrm{~m}^{-2}$. This effect is on average partially compensated by SWD decreases; the most notable decrease in SWD is reached in September 2010 with $-63 \mathrm{Wm}^{-2}$. As suggested by our simulations, the net drifting-snow radiative forcing is positive $\left(+6.1 \mathrm{~W} \mathrm{~m}^{-2}\right.$; mean value on all the unfiltered datasets), particularly during filtered conditions $\left(+24.5 \mathrm{~W} \mathrm{~m}^{-2}\right)$, even 


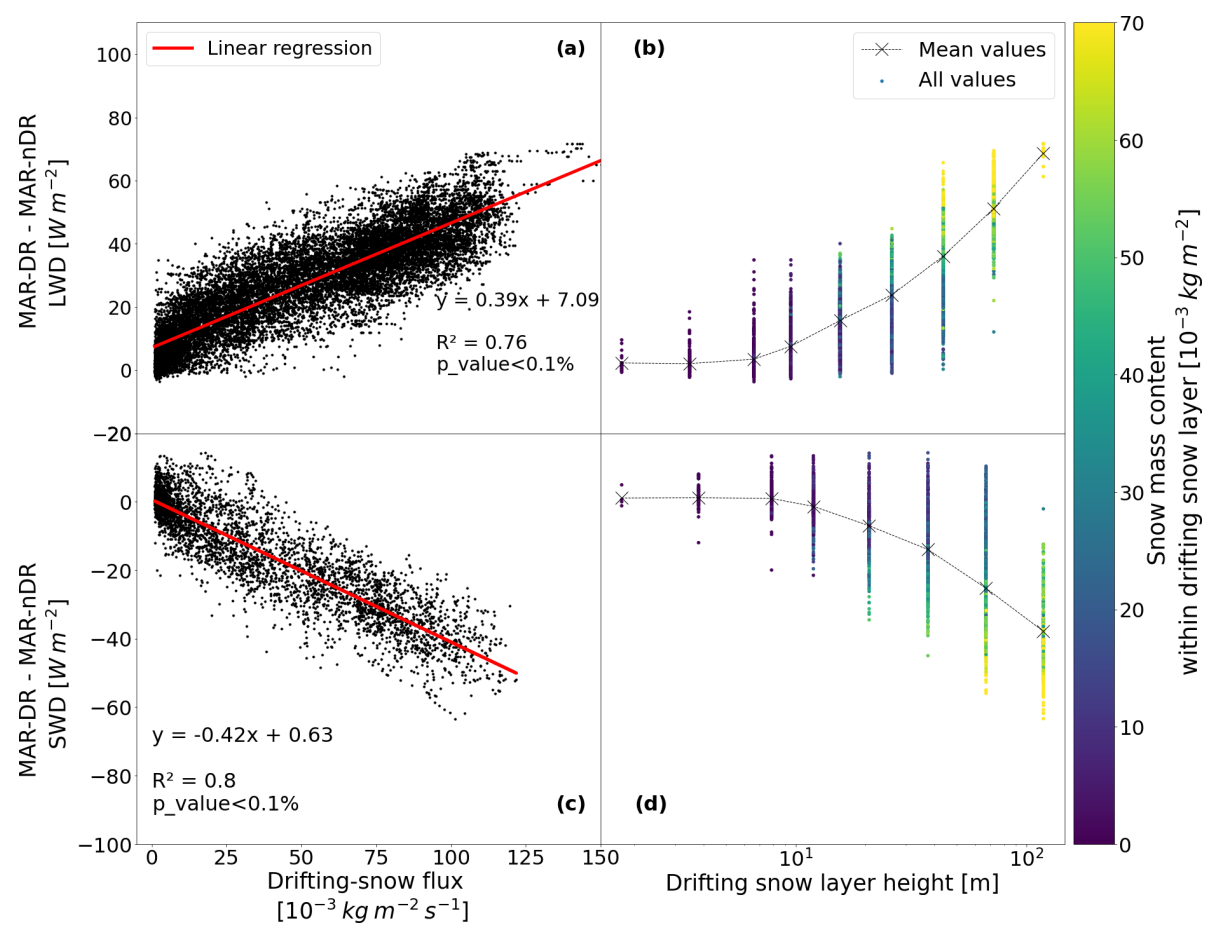

Figure 5. Modifications in (a) LWD and (c) SWD between MAR-DR and MAR-nDR during drifting snow (drifting-snow flux $>10^{-3} \mathrm{~kg} \mathrm{~m}^{2} \mathrm{~s}^{-1}$ ) as a function of drifting-snow flux for a mean flux calculated between 0 and $2 \mathrm{~m}$. The red line indicates the best linear regression between radiative modifications and drifting-snow fluxes. Regression functions and statistics are displayed on the corresponding panels. SWD modifications are computed when MAR-nDR simulates SWD $>50 \mathrm{~W} \mathrm{~m}^{-2}$. Data are filtered according to Sect. 2.4 . Modifications in (b) LWD and (d) SWD between MAR-DR and MAR-nDR during drifting snow (drifting-snow flux $>10^{-3} \mathrm{~kg} \mathrm{~m} \mathrm{~s}^{-1}$ ) as a function of drifting-snow layer height. The color bar indicates the mass of snow contained between the drifting-snow layer height and the surface. Mean values are calculated for the lowest nine model vertical levels and are represented by a gray mark. SWD modifications are computed when MAR-nDR simulates $\mathrm{SWD}>50 \mathrm{~W} \mathrm{~m}^{-2}$. Data are filtered according to Sect. 2.4.

when SWD are significant $\left(+12.8 \mathrm{~W} \mathrm{~m}^{-2}\right)$. The effect is more prominent during low solar irradiance periods because LWD is highly impacted, whereas SWD is absent (or very low) and cannot be modified. The additional radiative forcing due to drifting snow is higher when eroded snow particles predominantly contribute to the suspended snow mass.

Snow erosion and resulting drifting-snow sublimation modify the atmospheric composition in water species by introducing additional snow particles in the atmosphere and also enhancing its water vapor content, resulting in an increase in longwave emissivity (Yamanouchi and Kawaguchi, 1984). A sensitivity analysis was performed in order to distinguish and quantify the relative contribution of eroded snow particles and additional water vapor to modified radiative fluxes. In addition to MAR-DR and MAR-nDR, two other runs with and without drifting snow were performed for the year 2017 in which the radiative contribution of snow particles has been disabled. The difference between the two last runs were compared to differences between MAR-DR and MAR-nDR and demonstrated that incoming longwave modifications are predominantly due to the radiative contribution of drifting-snow particles (Fig. S2).

\section{Discussion}

\subsection{Impact on the boundary layer}

In the model at D17, the boundary layer is predominantly impacted in the first $600 \mathrm{~m}$ a.g.l. (lowest 11 vertical levels; Fig. 6). The snow particle ratio is high near the surface where snow erosion occurs and decreases rapidly with height above the surface (Fig. 6j). However, atmospheric sublimation peaks higher up (fourth model vertical level, $12 \mathrm{~m}$ ), as already suggested in, e.g., van den Broeke et al. (2006) and Amory and Kittel (2019). As drifting-snow sublimation is a self-limiting process inhibited by the development of nearsaturated layers close the surface (Bintanja, 2001), the maximum in atmospheric sublimation during drifting-snow events occurs higher up in the atmosphere where sublimation is favored by the undersaturation of the environment.

As observed by Palm et al. (2018), by using dropsondes across Antarctica, well-mixed layers with small vertical gradients in temperature and increasing relative humidity within proximity of the surface characterize the thermodynamic structure of drifting-snow layers. Figure 6 shows that both features are reproduced by MAR, with a well-mixed 

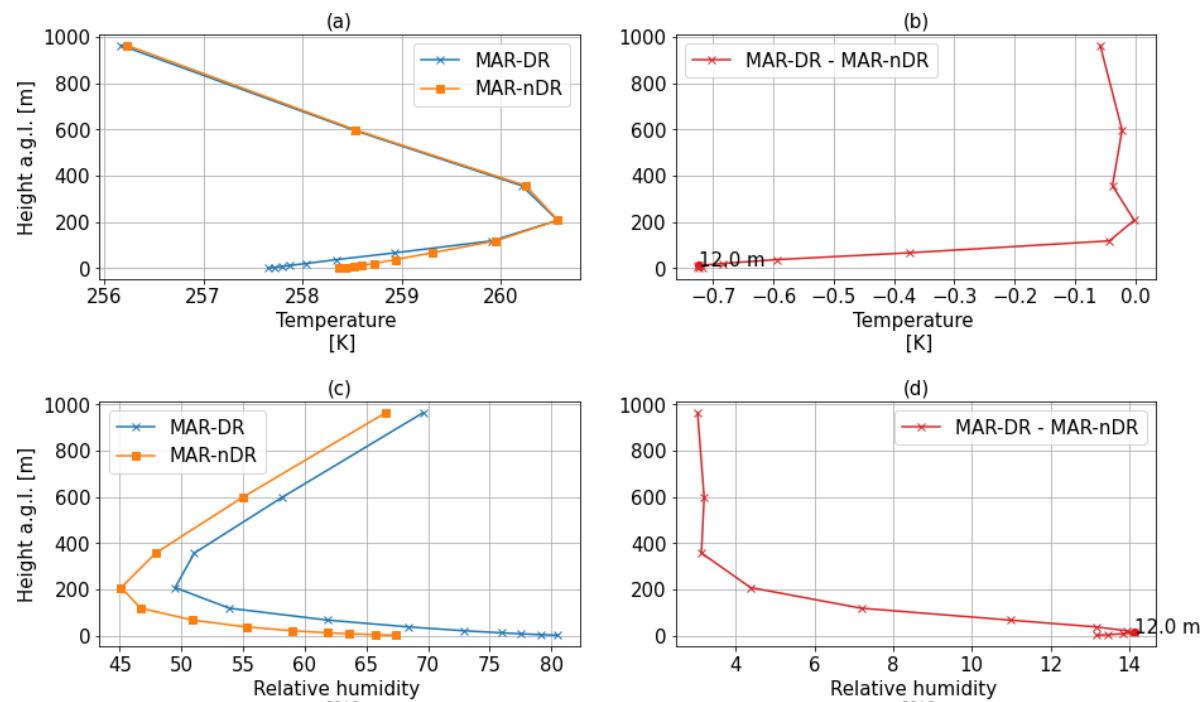

[\%]

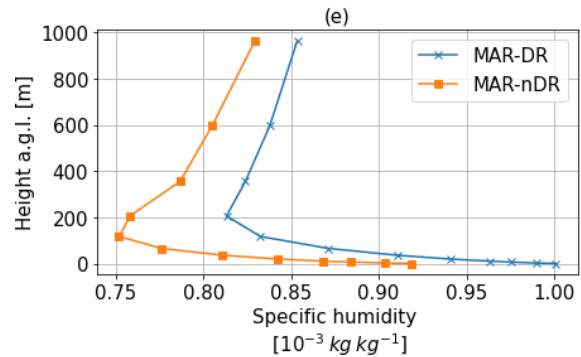

[\%]

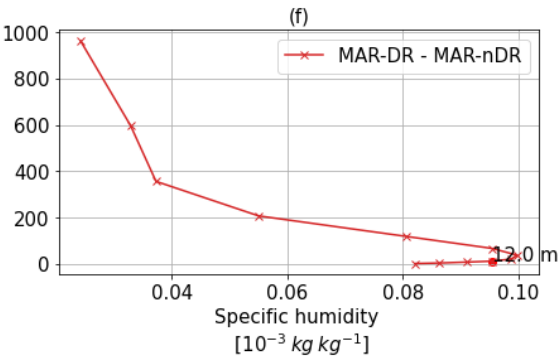

(g)
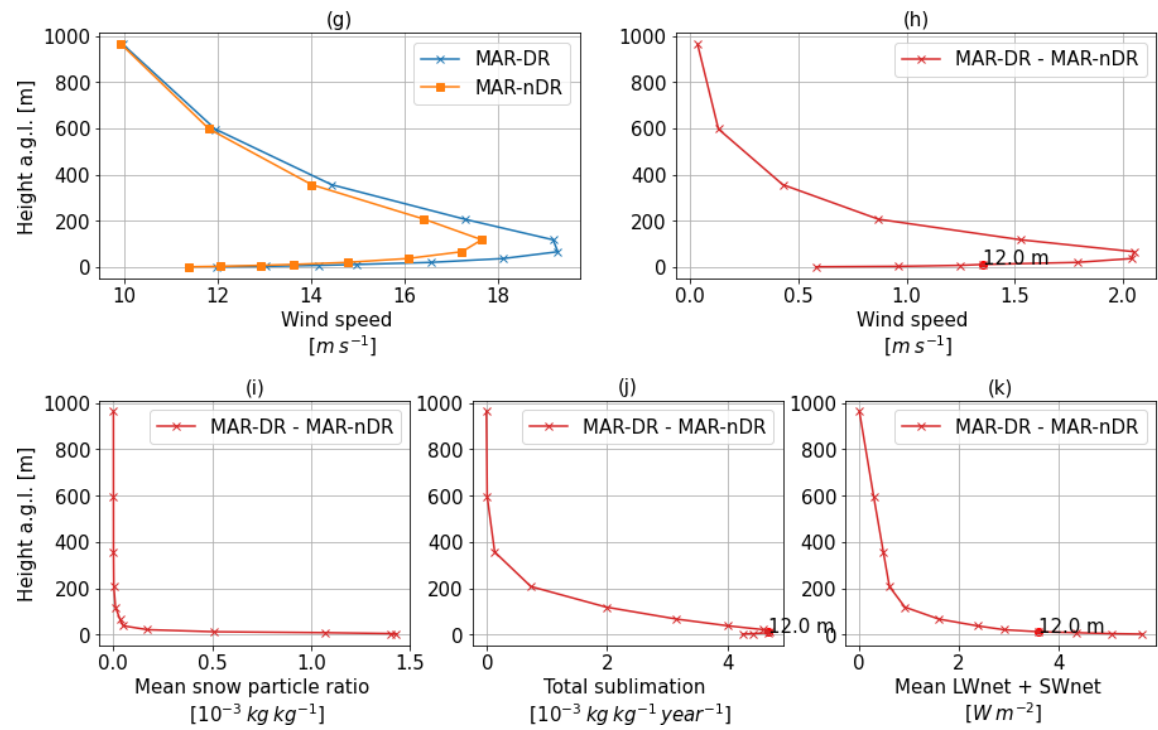

Figure 6. Annual mean (2010-2018) vertical profiles for near-surface and surface variables calculated at D17 on the lowest 12 vertical levels as simulated by MAR-DR, MAR-nDR, or the corresponding differences between both runs. In panel (i), sublimation rates are expressed in grams of sublimated snow per kilogram of moist air per year.

temperature structure $\left(<0.019 \mathrm{~K} \mathrm{~m}^{-1}\right)$ within the first $100 \mathrm{~m}$ above ground, i.e., near the average height of drifting-snow layers and a downward positive gradient in relative humidity. Further evaluation is, however, necessary to quantify the ability of the model to capture wind-shear induced turbulent mixing and warm-air entrainment within katabatic flows.

According to the vertical profiles in Fig. 6, increases in wind speed, relative humidity, and specific humidity and decreases in temperature are in accordance with increases in 

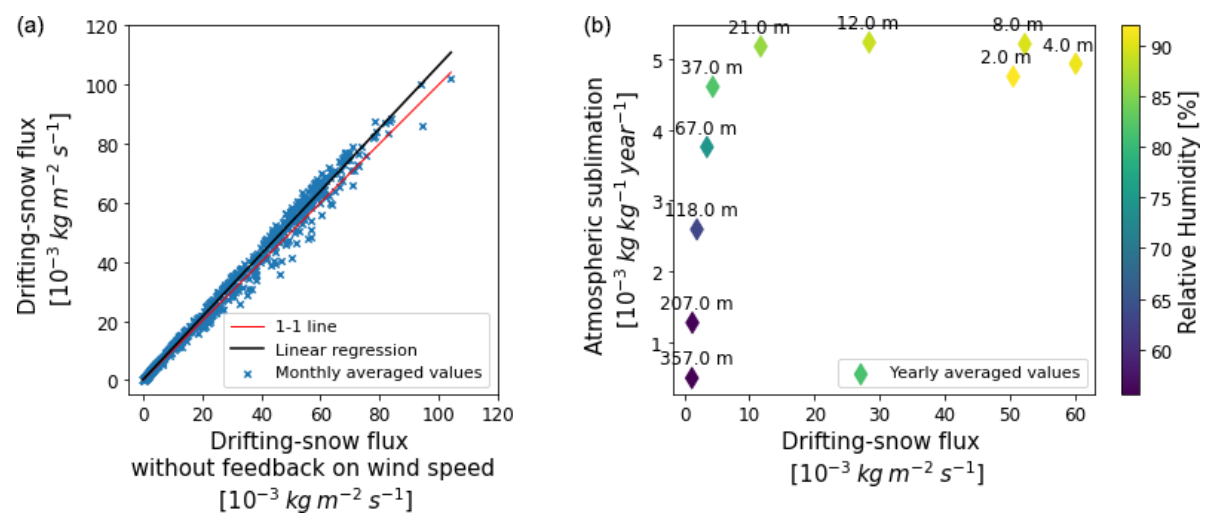

Figure 7. (a) Comparison between drifting-snow fluxes in the atmosphere calculated in MAR-DR using the usual wind speed values ( $y$ axis) or using wind speed values retrieved from the MAR-nDR simulation ( $x$ axis). The latter is done to approximate drifting-snow fluxes without accounting for the impact of drifting-snow sublimation on wind speeds. All fluxes are monthly averaged values over the 2010-2018 period computed at each of the 10 lowest model vertical levels. The black line denotes the best linear regression. Taking into account the atmospheric sublimation feedback on wind speed enhances drifting-snow fluxes. (b) Atmospheric sublimation as a function of drifting-snow fluxes for the 10 lowest model vertical levels. Values are averaged yearly to denote the model vertical level elevation (black text). Annual atmospheric sublimation rates are expressed in kilogram of sublimated snow mass per kilogram of moist air. The color bar indicates yearly averaged relative humidity at the considered level. Enhanced drifting-snow fluxes are responsible for increased atmospheric sublimation until a plateau is reached. This plateau coincides with the occurrence of near-saturated environments, where additional sublimation is limited by the negative feedback of sublimation.

atmospheric sublimation. All of these variables are predominantly modified in the drifting-snow layer when accounting for drifting snow. The modification intensity peaks in the vicinity of the vertical level experiencing maximum atmospheric sublimation. This suggests that atmospheric sublimation drives the impacts of drifting snow on the lowatmosphere meteorology at D17. Accounting for this phenomenon at each vertical level modifies the entire boundarylayer structure.

Wind speed increases in MAR-DR compared to MAR$\mathrm{nDR}$ at D17 (Fig. 6g, h). The largest increases are found at the sixth and seventh vertical levels $(38$ and $67 \mathrm{~m}$ ), near the level experiencing maximum sublimation (fourth vertical model level, $12 \mathrm{~m}$ ). As already suggested (e.g., Kodama et al., 1985), wind speed can increase during drifting snow events because of increased density of the air-snow mixture and an increased stable thermal stratification (Fig. 6a) caused by the atmospheric sublimation-induced cooling, which is a positive feedback on a sloping surface due to the gravitational nature of katabatic winds (Bintanja, 2000). This effect could be moderated at the lowest model vertical levels by surface-atmosphere interactions, such as the surface drag responsible for a decrease in wind speed. Further analysis reveals that incorporating snow particles in the calculation of the virtual potential temperature in order to simulate the contribution of snow particles to the air density has a small impact on wind speed in MAR-DR (Fig. S4). Finally, a supplementary analysis (Fig. S3) on the sensitivity of the katabatic forcing term to the inclusion of drifting snow is proposed through a computation of the potential temperature deficit in the low atmosphere at D17, following Van den Broeke and Van Lipzig (2003). Decreasing temperatures with increasing drifting-snow sublimation modify mean potential temperature in the boundary layer. Such modifications are responsible for an increase in katabatic forcing in MAR-DR. Moreover, higher wind speeds have the potential to (i) erode more snow, (ii) advect drifting-snow particles at higher elevations in a warmer and drier environment through turbulent mixing, and (iii) increase the residence time of drifting-snow particles in the atmosphere. Consequently, higher wind speeds trigger three factors that could potentially favor more atmospheric sublimation and constitute a positive feedback. We explore this feedback in Fig. 7a where MAR-DR driftingsnow fluxes are computed at each model vertical level and shown as monthly averages. Additionally, we performed the same computation by replacing the wind speed with the one from the simulation MAR-nDR, which is on average lower than in the MAR-DR simulation. We aim here at quantifying the absence of the positive feedback of sublimation on wind speed and its impact on drifting-snow fluxes. Figure 7 shows that stronger wind speeds reinforced by additional sublimation in the MAR-DR simulation are responsible for an increase in drifting-snow fluxes. Such driftingsnow fluxes are correlated with atmospheric sublimation in a logarithmic fashion (Fig. 7b); higher wind speeds induce higher drifting-snow fluxes, which are in turn responsible for enhanced atmospheric sublimation. Enhancement of sublimation is, however, limited by the self-limiting feedback of sublimation (Bintanja, 2001), the latter being dependent on the undersaturation of the ambient environment (see color 

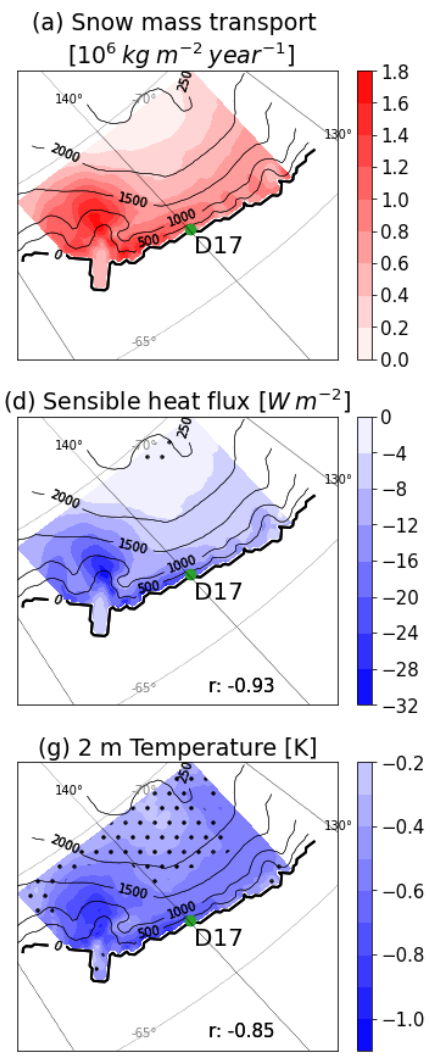
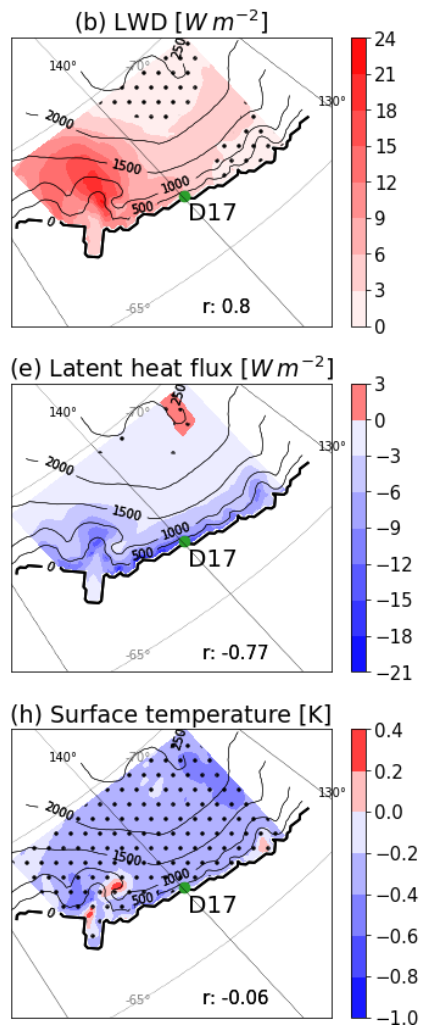
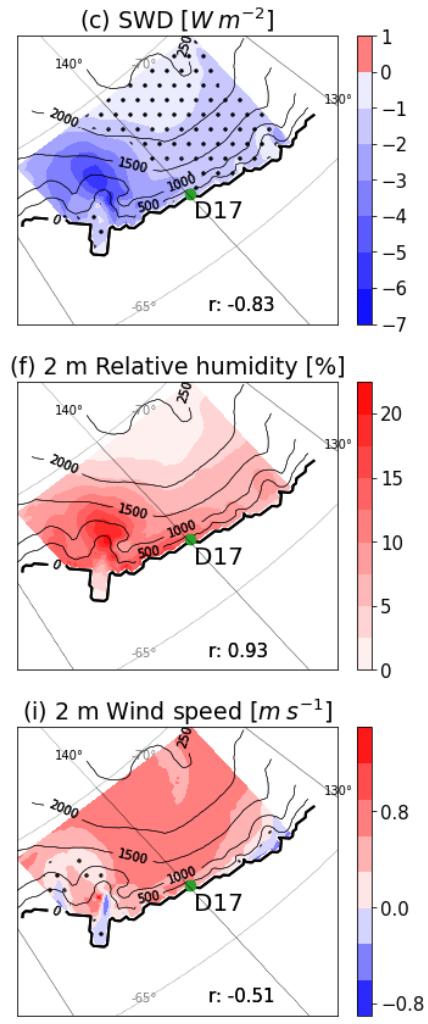

Figure 8. Annual mean (2010-2018) near-surface and surface variable modifications between MAR-DR and MAR-nDR over the integration domain. Within each panel, $r$ indicates the Pearson correlation coefficient between the snow mass transport anomaly (a) and the considered variable (b-i). Dotted areas designate areas where modifications are lower than interannual variability (taken as the standard deviation computed from annual means).

bar in Fig. 7b). Ultimately, our simulations suggest that the feedback of increased wind speed on atmospheric sublimation could be all the more important at higher elevations (e.g., sixth model vertical level, $38 \mathrm{~m}$ ), where the atmospheric sublimation potential is more sensitive to increases in driftingsnow fluxes due to a lower relative humidity.

Finally, we find that the net radiative budget (LWnet + SWnet) in the model vertical levels increases with the proximity of the surface, especially within the drifting-snow layer (Fig. 6k). This increase is due to suspended snow particles in the drifting-snow layer, which emit longwave radiation and trap heat, consequently inducing a warming effect that competes with cooling by sublimation. The comparison between MAR-DR and MAR-nDR indicates that the net effect is a decrease in atmospheric temperatures (Fig. 6a and b), so the model suggests that the cooling effect due to sublimation dominates.

\subsection{Spatial analysis}

By analyzing our simulation on a regional scale, we demonstrate that the results obtained at D17 remain consistent at the scale of the integration domain (Table 3).
Firstly, we estimate the drifting-snow magnitude on a regional scale by studying snow mass transport (Fig. 8a). We calculate the mass of snow transported at the lowest atmospheric level at each grid point every year and then calculate the annual mean values at each grid point. The spatial distribution of snow mass transport is closely related to wind speed (Amory et al., 2021). It is particularly enhanced where the topographic slope accentuates and favors channeling of katabatic winds, initiated in the upper plateau region where wind speed and erosion are low.

The main drift-induced modifications in surface and nearsurface variables described at D17 remain consistent at the scale of the integration domain. The spatial patterns of the differences in surface and near-surface variables correlate with spatial patterns of the snow mass transport as demonstrated by high and significant ( $p$ value $<0.01$ ) Pearson correlation coefficients (Fig. 8). Modifications added by the drifting-snow scheme are often larger than the interannual variability (Fig. 8, undotted areas). However, surface temperature and melt modifications (not shown) are poorly linked with snow mass transport (respectively, $r=-0.06$ and $r=$ 0.3 ), additional evidence that drifting snow does not modify the SEB significantly in the model. 
Table 3. Half-hourly mean value and standard deviation (SD) for several near-surface and surface meteorological variables computed on Adelie Land with MAR-DR and MAR-nDR. Differences between both model runs are attributed to drifting-snow processes.

\begin{tabular}{|c|c|c|c|c|c|c|}
\hline & \multicolumn{2}{|c|}{ MAR-DR } & \multicolumn{2}{|c|}{ MAR-nDR } & \multicolumn{2}{|c|}{ |MAR-DR| - |MAR-nDR| } \\
\hline & Mean value & SD & Mean value & SD & Mean value & SD \\
\hline $\operatorname{LWD}\left(\mathrm{W} \mathrm{m}^{-2}\right)$ & 162.4 & 22.1 & 156.3 & 20.8 & 6.1 & 1.3 \\
\hline LWU (W m ${ }^{-2}$ ) & -205.3 & 22.2 & -206.2 & 22.2 & -0.9 & 0 \\
\hline $\operatorname{SWD}\left(\mathrm{W} \mathrm{m}^{-2}\right)$ & 142.6 & 3.4 & 144.4 & 2.8 & -1.8 & 0.6 \\
\hline $\operatorname{SWU}\left(\mathrm{W} \mathrm{m}^{-2}\right)$ & -115.4 & 2.8 & -116.0 & 2.4 & -0.6 & 0.4 \\
\hline $\mathrm{LHF}\left(\mathrm{W} \mathrm{m}^{-2}\right)$ & -2.7 & 3.0 & -5.8 & 6.2 & -3.1 & -3.2 \\
\hline $\operatorname{SHF}\left(\mathrm{W} \mathrm{m}^{-2}\right)$ & 18.1 & 4.3 & 27.0 & 8.9 & -8.9 & -4.6 \\
\hline LWnet + SWnet $+\mathrm{LHF}+\mathrm{SHF}\left(\mathrm{W} \mathrm{m}^{-2}\right)$ & -0.3 & 0.3 & -0.2 & 0.3 & 0.1 & 0 \\
\hline Surface temperature $(\mathrm{K})$ & 244.6 & 6.7 & 244.9 & 6.7 & -0.3 & 0 \\
\hline $2 \mathrm{~m}$ temperature $(\mathrm{K})$ & 245.5 & 6.7 & 246.0 & 6.8 & -0.5 & -0.1 \\
\hline $2 \mathrm{~m}$ wind speed $\left(\mathrm{m} \mathrm{s}^{-1}\right)$ & 10.6 & 1.8 & 10.1 & 1.8 & 0.5 & 0 \\
\hline $2 \mathrm{~m}$ relative humidity $(\%)$ & 92.1 & 3.2 & 84.9 & 6.2 & 7.2 & 3.0 \\
\hline
\end{tabular}

We estimate the net drifting-snow radiative forcing on Adelie Land to be $+7.6 \mathrm{~W} \mathrm{~m}^{-2}$ and the impact on SEB (estimated by LWnet + SWnet $+\mathrm{LHF}+\mathrm{SHF}$ ) to be smaller than $0.03 \mathrm{~W} \mathrm{~m}^{-2}$. Further spatial analysis performed at different vertical levels and shown in the Supplement (Fig. S2) indicate that the drifting-snow impacts within the boundary layer simulated at D17 are also retrieved on a regional scale.

\subsection{Current limitations}

The validity of our results is affected, among other things, by uncertainties related to the absence of model evaluation concerning surface turbulent fluxes and vertical profiles (Fig. 6), the scarcity of radiative measurements in Adelie Land, and the current state of development of the model.

The vertical profiles presented in Fig. 6 have only been evaluated at $2 \mathrm{~m}$ a.g.l.; therefore, the behavior of the model and the potential benefit of accounting for drifting snow in order to capture more realistic atmospheric dynamics in the lower atmosphere still needs to be assessed. Daily radiosoundings are operated at the nearby permanent station of Dumont D'Urville. However, sufficient climatic disparity exists between the D17 location, situated on the marginal slope of the Antarctic continent, and Dumont d'Urville station, situated beyond the continent boundaries on an island approximately $15 \mathrm{~km}$ northeast of D17. Nevertheless there is good agreement with observed values for several meteorological variables (wind speed, relative humidity, temperature, drifting-snow flux, and incoming and outgoing radiative fluxes) and the fact that the model is well constrained at its boundaries by global reanalysis is an argument in favor of firstly studying model outputs at the lowest vertical level and then exploring its behavior at higher altitudes. Dropsondes observations near the D17 location or operation of radiosoundings from the ground at D17 would help assess model performance and uncertainties at higher elevation to complement near-surface observations.

Modifications in downwelling atmospheric radiation, induced by the inclusion of drifting snow in MAR, are consistent with former in situ estimates (Lesins et al., 2009; Mahesh et al., 2003; Yamanouchi and Kawaguchi, 1984; Yang et al., 2014) of the radiative contribution of suspended particles, suggesting that the model simulates a realistic radiative forcing. However, our results might be affected, among other things, by limitations in the vertical resolution of the model, which does not take into account the large variations in snow particle concentration over the first $2 \mathrm{~m}$ of the low troposphere and the limitations of the current radiative scheme (e.g., Delhasse et al., 2020) inherited from the ERA-40 reanalysis product (Uppala et al., 2005). Improved or regressed evaluation statistics when accounting for drifting snow can be linked with error compensation elsewhere in the model, independently from the ability of the model to accurately reproduce drifting-snow processes. Radiation measurements are scarce in Antarctica due to the harsh environmental conditions and the difficulty to deploy and maintain measurement sites in remote areas; thus, more in situ observations of radiative fluxes and drifting-snow layer properties are needed for a more in-depth evaluation of model results and, in our case, assessment of the temporal and spatial representativity of the interactions described at site D17.

Drifting-snow sublimation, defined here by the difference in atmospheric sublimation between MAR-DR and MAR-nDR over the first $1000 \mathrm{~m}$ above ground, equals on average $606 \mathrm{~mm}$ w.e. $\mathrm{yr}^{-1}$ on all the integration domain in Adelie Land, with higher values reported at D17 $\left(716 \mathrm{~mm}\right.$ w.e. $\left.\mathrm{yr}^{-1}\right)$. These rates are larger than previous in situ estimates of drifting-snow sublimation made in distinct parts of the continent (King et al., 1996, 2001) where the climate differs from the windy and (relatively warm) conditions of coastal Adelie Land. However, Palm et al. (2017), 
through remotely sensed data, and Lenaerts and van den Broeke (2012), using a regional climate model, report sublimation rates in Adelie Land that are more in agreement with our model estimates, though still 2 to 3 times lower.

Moreover, the inclusion of newly formed clouds in MARDR as discussed in Sect. 2.4 can contribute to the probable overestimation of drifting-snow sublimation rates in MARDR. The sublimation rates, as simulated by MAR, have not yet been directly compared to in situ measurements, although indirect comparisons have been made through the evaluation of near-surface air relative humidity and temperature. Accounting for drifting-snow sublimation in the present study has proven useful to modify the relative humidity of the lower atmosphere and help the model matching with observed relative humidity from the timescale of a single event (Fig. 2) to a seasonal scale (Fig. 3). The deployment of eddy-covariance systems, including highly sensitive hygrometers, could provide complementary atmospheric sublimation estimates to evaluate model simulations during calm to moderate conditions. However, using eddy-covariance devices during strong drifting-snow episodes remains a challenge as drifting-snow particles alter the observed signal and limit their use in Adelie Land (e.g., Bintanja and Reijmer, 2001). Moreover, including drifting snow in MAR shows large impacts on turbulent fluxes that compensate (and sometimes slightly override, e.g., at D17) modifications in radiative fluxes. Such a compensation also needs to be evaluated through comparison with direct in situ measurements of latent and sensible heat fluxes during drifting-snow occurrences to determine if MAR-DR simulates (more) realistic turbulent heat exchanges at the surface. Modeling hypotheses regarding drifting-snow particle distribution and subsequent sublimation rates could be better constrained using information derived from in situ optical measurements (e.g., Naaim-Bouvet et al., 2013).

Additionally, we introduced a method based on CALIPSO observations to estimate the height of a drifting-snow layer using model outputs. This method allows us to derive an objective criterion concerning snow concentration in the atmosphere to determine the presence (or not) of a driftingsnow layer and its height during specific meteorological conditions. This method is limited by the fact that it has only been developed for 8 years of CALIPSO observations collected near D17. Future work could focus on other locations in Antarctica to improve the determination of the snow concentration threshold by gathering more remotely sensed observations to be compared to model simulations. This could ultimately lead to an evaluation of modeled drifting-snow layer heights using CALIPSO observations on a specific test dataset. Ultimately, the use of a grounded lidar at D17 could provide complementary information concerning the vertical structure of drifting-snow layers.

Finally, we underline that independent modeling approaches sometimes lead to contrasted results, highlighting the uncertainty related to modeling choices. For example, en- ergy exchange following atmospheric sublimation can be accounted for in the SEB (Lenaerts and van den Broeke, 2012) or computed at every model vertical level (this study) and ultimately lead to distinct impacts of drifting snow on the simulated climate. Intercomparing drifting-snow models and related drifting-snow processes could be of a great interest for Antarctica's regional modeling community, and such work would require simulations performed under comparable conditions (e.g., same region, comparable horizontal and vertical resolution, and same boundary forcing).

\section{Summary and conclusion}

We investigated the impact of drifting snow on the low atmosphere and the surface in coastal Adelie Land by comparing two simulations, respectively, with and without drifting snow, performed with the latest version of the regional climate model MAR (MARv3.11) over a 9-year period. Simulating drifting snow leads to notable modifications in nearsurface and surface variables. Our results suggest such effects are mainly driven by additional sublimation of driftingsnow particles in the low-level atmosphere. Temperature decreases $(-0.5 \mathrm{~K}$ on average; $-0.7 \mathrm{~K}$ at D17) and relative humidity increases at $2 \mathrm{~m}$ a.g.1. $(+7.2 \%$ on average; $+13.3 \%$ at D17) when drifting snow is taken into account, as a result of the latent heat exchanges and the release of additional water vapor. Modifications in temperature and relative humidity are not largest at the surface where snow mass transport is the most intense, but peak higher in the drifting-snow layer at the fourth $(12 \mathrm{~m})$ atmospheric level in agreement with the magnitude of atmospheric sublimation.

Wind speed increases in MAR-DR compared to MAR$\mathrm{nDR}$ on the integration domain and at D17 (Fig. 6g, h). At D17, the largest increases are found at the sixth and seventh vertical levels (38 and $67 \mathrm{~m}$ ), near the level experiencing maximum sublimation (fourth vertical model level, $12 \mathrm{~m}$ ). Thus, we observe a strong influence of drifting-snow sublimation on the structure of the boundary layer in the model, highlighting the importance of computing latent heat exchanges at each vertical level. When compared to in situ data observed at D17, $2 \mathrm{~m}$ relative humidity representation is greatly improved. The RMSE is reduced from $15.8 \%$ to $9.5 \%$ and the mean bias is reduced from $-14.0 \%$ to $-0.7 \%$. Additionally, the $2 \mathrm{~m}$ temperature mean bias is also reduced (the RMSE equals 1.3 and $1.2 \mathrm{~K}$, respectively; the mean bias is reduced from 0.5 to $-0.2 \mathrm{~K}$ ).

We observe significant modifications in radiative and turbulent components of the SEB when taking into account drifting snow. The presence of a drifting-snow layer leads to modifications similar to the presence of a near-surface cloud, inducing enhanced LWD and decreased SWD. When the simulations are neither affected by snowfall nor drift-induced modifications in cloud structure (Sect. 2.4), we observed that the higher the drifting-snow flux or the thicker the drifting- 
snow layers, the greater the modifications in radiative fluxes. As a result, LWnet increases at the surface $\left(+7.0 \mathrm{~W} \mathrm{~m}^{-2}\right.$ on average), SWnet decreases $\left(-1.2 \mathrm{~W} \mathrm{~m}^{-2}\right.$ on average), and the net effect is a positive drifting-snow radiative forcing of $+5.8 \mathrm{~W} \mathrm{~m}^{-2}$. This is, however, mostly compensated for in the drifting-snow layer by drifting-snow sublimation and at the surface by changes in turbulent fluxes. Atmospheric sublimation cools the lower atmosphere and reduces temperature and humidity gradients between the surface and the atmosphere, inducing less latent heat consumed and less sensible heat provided at the surface. The net effect between modification in LHF and SHF is less energy being provided at the surface $\left(-5.8 \mathrm{~W} \mathrm{~m}^{-2}\right)$. Consequently, we observed negligible impact on energy supply at the surface and no significant impacts on surface temperature between simulations.

As a consequence, this study shows that differences in terms of surface temperature and heat budget are limited between MAR-DR and MAR-nDR simulation. However, the impacts on each energy flux are significant; changes compensate for each other. Consequently, calibrating MAR with surface temperature data would likely lead to similar scores in Antarctica for simulations accounting or not accounting for drifting-snow processes. Nevertheless, drifting snow is a major component of both the surface mass balance and atmospheric moisture budget in the windy coastal area of Adelie Land (Amory and Kittel, 2019; Amory et al., 2021). Thus, accurately accounting for drifting snow improves the ability of the model to capture the atmospheric thermodynamics and interactions with the surface in a current climate. As air moisture, LWD, SHF, and LHF could very likely vary in a changing climate, capturing drifting-snow processes is consequently key for higher confidence in climate and surface mass balance projections. Furthermore, drifting snow induces modifications in the snow isotopic composition. In addition to snow redistribution, which alters stratigraphy measurements, drifting-snow sublimation, as a major contributor to the air moisture budget, scrambles relationships between water-stable isotope composition and climatic variables (Bréant et al., 2019). Improving quantification of modeled drifting snow and related sublimation is a first step before (i) implementing isotopes in MAR and (ii) improving uncertainty assessment for climate reconstructions (Landais et al., 2017).

As illustrated in Sect. 4.1, drifting snow modifies the low-atmosphere structure and thermodynamics. In particular, larger moisture content and higher relative humidity in the drifting-snow layer reduces the capacity of the lowlevel atmosphere to sublimate snow particles during snowfall (Grazioli et al., 2017), potentially impacting modeled snowfall rates at the surface. By increasing atmospheric moisture, drifting snow can also impact cloud formation and physical properties. Lenaerts and van den Broeke (2012) reported increasing snowfall when accounting for drifting snow with RACMO2.1/ANT in peripheral regions of the ice sheet, including coastal Adelie Land. As a consequence, drifting snow may have additional impact on the SEB and SMB. These additional processes have not been investigated in our study, mainly because MAR-DR in its current version does not discriminate between eroded and cloud-originating snow particles. Drift-induced modifications in cloud structure and precipitation would benefit from further investigation and are left for future work. Separating eroded snow from snowfall particles in the model could enable prescription of different particle properties and pave the way for improvements in the representation of the drifting-snow radiative forcing and more generally in the representation of the drifting-snow impact on the low-atmosphere and ice sheet surface.

Data availability. Radiation data are available at Amory et al. (2020b). Meteorological and drifting-snow data are available at Amory et al. (2020a). MAR simulations are freely available by contacting the authors.

Supplement. The supplement related to this article is available online at: https://doi.org/10.5194/tc-15-3595-2021-supplement.

Author contributions. LLT, CA, and VF designed the study. CA ran the simulations. LLT post-processed the data and wrote the first draft. CA, CK, XF, and HG developed the model. VK processed CALIPSO data. CA and VF collected field data. All authors contributed to the manuscript and discussed the results.

Competing interests. The authors declare that they have no conflict of interest.

Disclaimer. Publisher's note: Copernicus Publications remains neutral with regard to jurisdictional claims in published maps and institutional affiliations.

Acknowledgements. The authors thank all of the on-site personnel in Dumont d'Urville and Cap Prud'homme for their precious help in the field.

Financial support. This work would not have been possible without the financial and logistical support of the French Polar Institute IPEV (program CALVA-1013 and GLACIOCLIM-SAMBA411) and of the French Agence Nationale de la Recherche (projects ANR-14-CE01-0001 (ASUMA) and ANR-16-CE01-0011 (EAIIST)). Computational resources have been provided by the Consortium des Équipements de Calcul Intensif (CÉCI), funded by Fonds de la Recherche Scientifique de Belgique (FRS-FNRS) under grant no. 2.5020.11, and the Tier-1 supercomputer (Zenobe) of the Fédération Wallonie-Bruxelles infrastructure funded by the Walloon Region under grant agreement no. 1117545. 
Review statement. This paper was edited by David Schroeder and reviewed by two anonymous referees.

\section{References}

Agosta, C., Amory, C., Kittel, C., Orsi, A., Favier, V., Gallée, H., van den Broeke, M. R., Lenaerts, J. T. M., van Wessem, J. M., van de Berg, W. J., and Fettweis, X.: Estimation of the Antarctic surface mass balance using the regional climate model MAR (19792015) and identification of dominant processes, The Cryosphere, 13, 281-296, https://doi.org/10.5194/tc-13-281-2019, 2019.

Amory, C.: Drifting-snow statistics from multiple-year autonomous measurements in Adélie Land, East Antarctica, The Cryosphere, 14, 1713-1725, https://doi.org/10.5194/tc-14-1713-2020, 2020.

Amory, C. and Kittel, C.: Brief communication: Rare ambient saturation during drifting snow occurrences at a coastal location of East Antarctica, The Cryosphere, 13, 3405-3412, https://doi.org/10.5194/tc-13-3405-2019, 2019.

Amory, C., Trouvilliez, A., Gallée, H., Favier, V., Naaim-Bouvet, F., Genthon, C., Agosta, C., Piard, L., and Bellot, H.: Comparison between observed and simulated aeolian snow mass fluxes in Adélie Land, East Antarctica, The Cryosphere, 9, 1373-1383, https://doi.org/10.5194/tc-9-1373-2015, 2015.

Amory, C., Genthon, C., and Favier, V.: A drifting snow data set (2010-2018) from coastal Adelie Land, Eastern Antarctica, Zenodo, https://doi.org/10.5281/zenodo.3630497, 2020a.

Amory, C., Le Toumelin, L., Favier, V., and Genthon, C.: Radiation data (2014-2019) at site D17 (Adelie Land, East Antarctica), Zenodo, https://doi.org/10.5281/zenodo.4139737, 2020b.

Amory, C., Kittel, C., Le Toumelin, L., Agosta, C., Delhasse, A., Favier, V., and Fettweis, X.: Performance of MAR (v3.11) in simulating the drifting-snow climate and surface mass balance of Adélie Land, East Antarctica, Geosci. Model Dev., 14, 34873510, https://doi.org/10.5194/gmd-14-3487-2021, 2021.

Barral, H., Genthon, C., Trouvilliez, A., Brun, C., and Amory, C.: Blowing snow in coastal Adélie Land, Antarctica: three atmospheric-moisture issues, The Cryosphere, 8, 1905-1919, https://doi.org/10.5194/tc-8-1905-2014, 2014.

Bintanja, R.: On the glaciological, meteorological, and climatological significance of Antarctic blue ice areas, Rev. Geophys., 37, 337-359, https://doi.org/10.1029/1999RG900007, 1999.

Bintanja, R.: Snowdrift suspension and atmospheric turbulence. Part I: Theoretical background and model description, Bound.-Lay. Meteorol., 95, 343-368, https://doi.org/10.1023/A:1002676804487, 2000.

Bintanja, R.: Snowdrift Sublimation in a Katabatic Wind Region of the Antarctic Ice Sheet, J. Appl. Meteorol., 40, 1952-1966, https://doi.org/10.1175/15200450(2001)040<1952:SSIAKW>2.0.CO;2, 2001.

Bintanja, R. and Reijmer, C. H.: A simple parameterization for snowdrift sublimation over Antarctic snow surfaces, J. Geophys. Res.-Atmos., 106, 31739-31748, 2001.

Brun, E., David, P., Sudul, M., and Brunot, G.: A numerical model to simulate snow-cover stratigraphy for operational avalanche forecasting, J. Glaciol., 38, 13-22, https://doi.org/10.3189/S0022143000009552, 1992.

Bréant, C., Leroy Dos Santos, C., Agosta, C., Casado, M., Fourré, E., Goursaud, S., Masson-Delmotte, V., Favier, V.,
Cattani, O., Prié, F., Golly, B., Orsi, A., Martinerie, P., and Landais, A.: Coastal water vapor isotopic composition driven by katabatic wind variability in summer at Dumont d'Urville, coastal East Antarctica, Earth Planet. Sc. Lett., 514, 37-47, https://doi.org/10.1016/j.epsl.2019.03.004, 2019.

Cierco, F.-X., Naaim-Bouvet, F., and Bellot, H.: Acoustic sensors for snowdrift measurements: How should they be used for research purposes?, Cold Reg. Sci. Technol., 49, 74-87, https://doi.org/10.1016/j.coldregions.2007.01.002, 2007.

De Ridder, K. and Gallée, H.: Land Surface-Induced Regional Climate Change in Southern Israel, J. Appl. Meteorol., 37, 1470-1485, https://doi.org/10.1175/15200450(1998)037<1470:LSIRCC>2.0.CO;2, 1998.

Delhasse, A., Kittel, C., Amory, C., Hofer, S., van As, D., S. Fausto, R., and Fettweis, X.: Brief communication: Evaluation of the near-surface climate in ERA5 over the Greenland Ice Sheet, The Cryosphere, 14, 957-965, https://doi.org/10.5194/tc14-957-2020, 2020.

Déry, S. J., Taylor, P. A., and Xiao, J.: The thermodynamic effects of sublimating, blowing snow in the atmospheric boundary layer, Bound.-Lay. Meteorol., 89, 251-283, https://doi.org/10.1023/A:1001712111718, 1998.

Ebert, E. E. and Curry, J. A.: A parameterization of ice cloud optical properties for climate models, J. Geophys. Res.-Atmos., 97, 3831-3836, https://doi.org/10.1029/91JD02472, 1992.

Edwards, T. L., Brandon, M. A., Durand, G., Edwards, N. R., Golledge, N. R., Holden, P. B., Nias, I. J., Payne, A. J., Ritz, C., and Wernecke, A.: Revisiting Antarctic ice loss due to marine ice-cliff instability, Nature, 566, 58-64, https://doi.org/10.1038/s41586-019-0901-4, 2019.

Favier, V., Agosta, C., Genthon, C., Arnaud, L., Trouvillez, A., and Gallée, H.: Modeling the mass and surface heat budgets in a coastal blue ice area of Adelie Land, Antarctica, J. Geophys. Res.-Ea. Surf., 116, F03017, https://doi.org/10.1029/2010JF001939, 2011.

Favier, V., Krinner, G., Amory, C., Gallée, H., Beaumet, J., and Agosta, C.: Antarctica-regional climate and surface mass budget, Curr. Clim. Change Rep., 3, 303-315, https://doi.org/10.1007/s40641-017-0072-z, 2017.

Fettweis, X., Box, J. E., Agosta, C., Amory, C., Kittel, C., Lang, C., van As, D., Machguth, H., and Gallée, H.: Reconstructions of the 1900-2015 Greenland ice sheet surface mass balance using the regional climate MAR model, The Cryosphere, 11, 1015-1033, https://doi.org/10.5194/tc-11-1015-2017, 2017.

Fettweis, X., Hofer, S., Krebs-Kanzow, U., Amory, C., Aoki, T., Berends, C. J., Born, A., Box, J. E., Delhasse, A., Fujita, K., Gierz, P., Goelzer, H., Hanna, E., Hashimoto, A., Huybrechts, P., Kapsch, M.-L., King, M. D., Kittel, C., Lang, C., Langen, P. L., Lenaerts, J. T. M., Liston, G. E., Lohmann, G., Mernild, S. H., Mikolajewicz, U., Modali, K., Mottram, R. H., Niwano, M., Noël, B., Ryan, J. C., Smith, A., Streffing, J., Tedesco, M., van de Berg, W. J., van den Broeke, M., van de Wal, R. S. W., van Kampenhout, L., Wilton, D., Wouters, B., Ziemen, F., and Zolles, T.: GrSMBMIP: intercomparison of the modelled 19802012 surface mass balance over the Greenland Ice Sheet, The Cryosphere, 14, 3935-3958, https://doi.org/10.5194/tc-14-39352020, 2020.

Gallee, H.: Simulation of the mesocyclonic activity in the Ross Sea, Antarctica, Mon. Weather Rev., 123, 2051-2069, 1995. 
Gallée, H. and Gorodetskaya, I. V.: Validation of a limited area model over Dome C, Antarctic Plateau, during winter, Clim. Dynam., 34, 61, https://doi.org/10.1007/S00382-008-0499-Y, 2010.

Gallée, H., Guyomarc'h, G., and Brun, E.: Impact of snow drift on the Antarctic ice sheet surface mass balance: possible sensitivity to snow-surface properties, Bound.-Lay. Meteorol., 99, 1-19, https://doi.org/10.1023/A:1018776422809, 2001.

Gallée, H.: Simulation of blowing snow over the antarctic ice sheet, Ann. Glaciol., 26, 203-206, https://doi.org/10.3189/1998AoG26-1-203-206, 1998.

Gallée, H. and Duynkerke, P. G.: Air-snow interactions and the surface energy and mass balance over the melting zone of west Greenland during the Greenland Ice Margin Experiment, J. Geophys. Res.-Atmos., 102, 13813-13824, https://doi.org/10.1029/96JD03358, 1997.

Gallée, H. and Schayes, G.: Development of a Three-Dimensional Meso- $\gamma$ Primitive Equation Model: Katabatic Winds Simulation in the Area of Terra Nova Bay, Antarctica, Mon. Weather Rev., 122, 671-685, https://doi.org/10.1175/15200493(1994)122<0671:DOATDM>2.0.CO;2, 1994.

Gallée, H., Peyaud, V., and Goodwin, I.: Simulation of the net snow accumulation along the Wilkes Land transect, Antarctica, with a regional climate model, Ann. Glaciol., 41, 17-22, https://doi.org/10.3189/172756405781813230, 2005.

Gallée, H., Trouvilliez, A., Agosta, C., Genthon, C., Favier, V., and Naaim-Bouvet, F.: Transport of Snow by the Wind: A Comparison Between Observations in Adélie Land, Antarctica, and Simulations Made with the Regional Climate Model MAR, Bound.Lay. Meteorol., 146, 133-147, https://doi.org/10.1007/s10546012-9764-z, 2013.

Goff, J. A. and Gratch, S.: Thermodynamic properties of moist air, Trans. ASHVE, 51, 125, 1945.

Gossart, A., Souverijns, N., Gorodetskaya, I. V., Lhermitte, S., Lenaerts, J. T. M., Schween, J. H., Mangold, A., Laffineur, Q., and van Lipzig, N. P. M.: Blowing snow detection from ground-based ceilometers: application to East Antarctica, The Cryosphere, 11, 2755-2772, https://doi.org/10.5194/tc-11-27552017, 2017.

Grazioli, J., Genthon, C., Boudevillain, B., Duran-Alarcon, C., Del Guasta, M., Madeleine, J.-B., and Berne, A.: Measurements of precipitation in Dumont d'Urville, Adélie Land, East Antarctica, The Cryosphere, 11, 1797-1811, https://doi.org/10.5194/tc-111797-2017, 2017.

Hanna, E., Pattyn, F., Navarro, F., Favier, V., Goelzer, H., van den Broeke, M. R., Vizcaino, M., Whitehouse, P. L., Ritz, C., Bulthuis, K., and Smith, B.: Mass balance of the ice sheets and glaciers - Progress since AR5 and challenges, Earth-Sci. Rev., 201, 102976, https://doi.org/10.1016/j.earscirev.2019.102976, 2020.

Hersbach, H., Bell, B., Berrisford, P., Hirahara, S., Horányi, A., Muñoz-Sabater, J., Nicolas, J., Peubey, C., Radu, R., Schepers, D., Simmons, A., Soci, C., Abdalla, S., Abellan, X., Balsamo, G., Bechtold, P., Biavati, G., Bidlot, J., Bonavita, M., De Chiara, G., Dahlgren, P., Dee, D., Diamantakis, M., Dragani, R., Flemming, J., Forbes, R., Fuentes, M., Geer, A., Haimberger, L., Healy, S., Hogan, R. J., Hólm, E., Janisková, M., Keeley, S., Laloyaux, P., Lopez, P., Lupu, C., Radnoti, G., de Rosnay, P., Rozum, I., Vamborg, F., Villaume, S., and Thépaut, J.-N.: The
ERA5 global reanalysis, Q. J. Roy. Meteor. Soc., 146, 19992049, https://doi.org/10.1002/qj.3803, 2020.

Hofer, S., Tedstone, A. J., Fettweis, X., and Bamber, J. L.: Decreasing cloud cover drives the recent mass loss on the Greenland Ice Sheet, Sci. Adv., 3, e1700584, https://doi.org/10.1126/sciadv.1700584, 2017.

Hofer, S., Tedstone, A. J., Fettweis, X., and Bamber, J. L.: Cloud microphysics and circulation anomalies control differences in future Greenland melt, Nat. Clim. Change, 9, 523-528, https://doi.org/10.1038/s41558-019-0507-8, 2019.

King, J., Anderson, P., Smith, M., and Mobbs, S.: The surface energy and mass balance at Halley, Antarctica during winter, J. Geophys. Res.-Atmos., 101, 19119-19128, 1996.

King, J., Anderson, P., and Mann, G.: The seasonal cycle of sublimation at Halley, Antarctica, J. Glaciol., 47, 1-8, 2001.

Kittel, C., Amory, C., Agosta, C., Delhasse, A., Doutreloup, S., Huot, P.-V., Wyard, C., Fichefet, T., and Fettweis, X.: Sensitivity of the current Antarctic surface mass balance to sea surface conditions using MAR, The Cryosphere, 12, 3827-3839, https://doi.org/10.5194/tc-12-3827-2018, 2018.

Kittel, C., Amory, C., Agosta, C., Jourdain, N. C., Hofer, S., Delhasse, A., Doutreloup, S., Huot, P.-V., Lang, C., Fichefet, T., and Fettweis, X.: Diverging future surface mass balance between the Antarctic ice shelves and grounded ice sheet, The Cryosphere, 15, 1215-1236, https://doi.org/10.5194/tc-15-1215-2021, 2021.

Kodama, Y., Wendler, G., and Gosink, J.: The Effect of Blowing Snow on Katabatic Winds in Antarctica, Ann. Glaciol., 6, 59-62, https://doi.org/10.3189/1985AoG6-1-59-62, 1985.

Landais, A., Casado, M., Prié, F., Magand, O., Arnaud, L., Ekaykin, A., Petit, J.-R., Picard, G., Fily, M., Minster, B., Touzeau, A., Goursaud, S., Masson-Delmotte, V., Jouzel, J., and Orsi, A.: Surface studies of water isotopes in Antarctica for quantitative interpretation of deep ice core data, C. R. Geosci., 349, 139-150, https://doi.org/10.1016/j.crte.2017.05.003, 2017.

Lenaerts, J. T. M. and van den Broeke, M. R.: Modeling drifting snow in Antarctica with a regional climate model: 2. Results, J. Geophys. Res.-Atmos., 117, D05109, https://doi.org/10.1029/2010JD015419, 2012.

Lesins, G., Bourdages, L., Duck, T. J., Drummond, J. R., Eloranta, E. W., and Walden, V. P.: Large surface radiative forcing from topographic blowing snow residuals measured in the High Arctic at Eureka, Atmos. Chem. Phys., 9, 1847-1862, https://doi.org/10.5194/acp-9-1847-2009, 2009.

Lin, Y.-L., Farley, R. D., and Orville, H. D.: Bulk Parameterization of the Snow Field in a Cloud Model, J. Clim. Appl. Meteorol., 22, 1065-1092, https://doi.org/10.1175/15200450(1983)022<1065:BPOTSF>2.0.CO;2, 1983.

Locatelli, J. D. and Hobbs, P. V.: Fall speeds and masses of solid precipitation particles, J. Geophys. Res., 79, 2185-2197, 1974.

Mahesh, A., Eager, R., Campbell, J. R., and Spinhirne, J. D.: Observations of blowing snow at the South Pole, J. Geophys. Res.-Atmos., 108, 4707, https://doi.org/10.1029/2002JD003327, 2003.

Mann, G. W., Anderson, P. S., and Mobbs, S. D.: Profile measurements of blowing snow at Halley, Antarctica, J. Geophys. Res., 105, 24491-24508, https://doi.org/10.1029/2000JD900247, 2000.

Morcrette, J.-J.: Assessment of the ECMWF Model Cloudiness and Surface Radiation Fields at the ARM SGP Site, 
Mon. Weather Rev., 130, 257-277, https://doi.org/10.1175/15200493(2002)130<0257:AOTEMC>2.0.CO;2, 2002.

Mottram, R., Hansen, N., Kittel, C., van Wessem, M., Agosta, C., Amory, C., Boberg, F., van de Berg, W. J., Fettweis, X., Gossart, A., van Lipzig, N. P. M., van Meijgaard, E., Orr, A., Phillips, T., Webster, S., Simonsen, S. B., and Souverijns, N.: What is the Surface Mass Balance of Antarctica? An Intercomparison of Regional Climate Model Estimates, The Cryosphere Discuss. [preprint], https://doi.org/10.5194/tc-2019-333, in review, 2020.

Naaim-Bouvet, F., Guyomarc'H, G., Bellot, H., Durand, Y., Naaim,M., Vionnet, V., Genthon, C., Nishimura, K., Ito, Y., and Prokop, A.: Lac Blanc Pass: a natural wind-tunnel for studying drift-ing snow at $2700 \mathrm{~m}$ a.s.1., in: International Snow Science Work-shop (ISSW), 1332, Irstea, French Association for Snow and Avalanche Study, Meteo France, Grenoble - Chamonix Mont-Blanc, October 2013.

Palm, S. P., Yang, Y., Spinhirne, J. D., and Marshak, A.: Satellite remote sensing of blowing snow properties over Antarctica, J. Geophys. Res.-Atmos., 116, D16123, https://doi.org/10.1029/2011JD015828, 2011.

Palm, S. P., Kayetha, V., Yang, Y., and Pauly, R.: Blowing snow sublimation and transport over Antarctica from 11 years of CALIPSO observations, The Cryosphere, 11, 2555-2569, https://doi.org/10.5194/tc-11-2555-2017, 2017.

Palm, S. P., Kayetha, V., and Yang, Y.: Toward a SatelliteDerived Climatology of Blowing Snow Over Antarctica, J. Geophys. Res.-Atmos., 123, 10301-10313, https://doi.org/10.1029/2018JD028632, 2018.

Scarchilli, C., Frezzotti, M., Grigioni, P., De Silvestri, L., Agnoletto, L., and Dolci, S.: Extraordinary blowing snow transport events in East Antarctica, Clim. Dynam., 34, 1195-1206, https://doi.org/10.1007/s00382-009-0601-0, 2010.

Schmidt, R.: Vertical profiles of wind speed, snow concentration, and humidity in blowing snow, Bound.-Lay. Meteorol., 23, 223246, https://doi.org/10.1007/BF00123299, 1982.

Shepherd, A., Ivins, E., Rignot, E., Smith, B., Van Den Broeke, M.,Velicogna, I., Whitehouse, P., Briggs, K., Joughin, I., Krinner, G., Nowicki, S., Payne, T., Scambos, T., Schlegel, N., A, G., Agosta, C., Ahlstrøm, A., Babonis, G., Barletta, V., Blazquez, A., Bonin, J., Csatho, B., Cullather, R., Felikson, D., Fettweis, X., Forsberg, R., Gallee, H., Gardner, A., Gilbert, L. Groh, A., Gunter, B., Hanna, E., Harig, C., Helm, V., Horvath, A., Horwath M., Khan, S., Kjeldsen, K., Konrad, H., Langen P., Lecavalier, B., Loomis, B., Luthcke, S., McMilla,, M., Melini, D., Mernild, S., Mohajerani, Y., Moore, P., Mouginot, J., Moyano, G., Muir, A., Nagler, T., Nield, G., Nilsson, J., Noel, B., Otosaka, I., Pattle, M., Peltier, R., Pie, N., Rietbroek R., Rott, H., Sandberg-Sørensen, L., Sasgen, I., Save, H., Scheuchl, B., Schrama, E., Schröder, L., Seo, K.-W., Simonsen, S., Slater, T., Spada, G., Sutterley, T., Talpe M., Tarasov, L., van den Berg, W., van der Wal, W., van Wessem, M., Vishwakarma, B., Wiese, D., and Wouters, B: Mass balance of the Antarctic Ice Sheet from 1992 to 2017, Nature, 558, 219-222, https://doi.org/10.1038/s41586-018-0179-y, 2018.

Taylor, K. E.: Summarizing multiple aspects of model performance in a single diagram, J. Geophys. Res.-Atmos., 106, 7183-7192, https://doi.org/10.1029/2000JD900719, 2001.
Town, M. S., Walden, V. P., and Warren, S. G.: Cloud Cover over the South Pole from Visual Observations, Satellite Retrievals, and Surface-Based Infrared Radiation Measurements, J. Climate, 20, 544-559, https://doi.org/10.1175/JCLI4005.1, 2007.

Trouvilliez, A., Naaim-Bouvet, F., Genthon, C., Piard, L., Favier, V., Bellot, H., Agosta, C., Palerme, C., Amory, C., and Gallée, H.: A novel experimental study of aeolian snow transport in Adelie Land (Antarctica), Cold Reg. Sci. Technol., 108, 125138, https://doi.org/10.1016/j.coldregions.2014.09.005, 2014.

Trouvilliez, A., Naaim-Bouvet, F., Bellot, H., Genthon, C., and Gallée, H.: Evaluation of the FlowCapt Acoustic Sensor for the Aeolian Transport of Snow, J. Atmos. Ocean. Tech., 32, 1630-1641, https://doi.org/10.1175/JTECH-D-14-00104.1, 2015.

Uppala, S. M., Kållberg, P. W., Simmons, A. J., Andrae, U., Da Costa Bechtold, V., Fiorino, M., Gibson, J.K., Haseler, J., Hernandez, A., Kelly, G. A., Li, X., Onogi, K., Saarinen, S., Sokka, N., Allan, R. P., Anderson, E., Arpe, K., Balmaseda, M. A., Beljaars, A. C. M., Van De Berg, L., Bidlot, J., Bormann, N., Caires, S., Chevallier, F., Dethof, A., Dragosavac, M., Fisher, M., Fuentes, M., Hagemann, S., Hólm, E., Hoskins, B. J., Isaksen, L., Janssen, P. A. E. M., Jenne, R., Mcnally, A. P., Mahfouf, J.-F., Morcrette, J.-J., Rayner, N. A., Saunders, R. W., Simon, P., Sterl, A., Trenbreth, K. E., Untch, A., Vasiljevic, D., Viterbo, P., and Woollen, J.: The ERA-40 re-analysis, Q. J. Roy. Meteor. Soc., 131, 2961-3012, https://doi.org/10.1256/qj.04.176, 2005.

Van den Broeke, M. and Van Lipzig, N.: Factors controlling the near-surface wind field in Antarctica, Mon. Weather Rev., 131, 733-743, 2003.

van den Broeke, M., van de Berg, W. J., van Meijgaard, E., and Reijmer, C.: Identification of Antarctic ablation areas using a regional atmospheric climate model, J. Geophys. Res.-Atmos., 111, D18110, https://doi.org/10.1029/2006JD007127, 2006.

van Wessem, J. M., van de Berg, W. J., Noël, B. P. Y., van Meijgaard, E., Amory, C., Birnbaum, G., Jakobs, C. L., Krüger, K., Lenaerts, J. T. M., Lhermitte, S., Ligtenberg, S. R. M., Medley, B., Reijmer, C. H., van Tricht, K., Trusel, L. D., van Ulft, L. H., Wouters, B., Wuite, J., and van den Broeke, M. R.: Modelling the climate and surface mass balance of polar ice sheets using RACMO2 Part 2: Antarctica (1979-2016), The Cryosphere, 12, 1479-1498, https://doi.org/10.5194/tc-12-1479-2018, 2018.

Vignon, E., Genthon, C., Barral, H., Amory, C., Picard, G., Gallée, H., Casasanta, G., and Argentini, S.: Momentum-and heatflux parametrization at Dome C, Antarctica: A sensitivity study, Bound.-Lay. Meteorol., 162, 341-367, 2017.

Yamanouchi, T. and Kawaguchi, S.: Longwave radiation balance under a strong surface inversion in the Katabatic Wind Zone, Antarctica, J. Geophys. Res.-Atmos., 89, 11771-11778, https://doi.org/10.1029/JD089iD07p11771, 1984.

Yang, Y., Palm, S. P., Marshak, A., Wu, D. L., Yu, H., and $\mathrm{Fu}, \mathrm{Q}$.: First satellite-detected perturbations of outgoing longwave radiation associated with blowing snow events over Antarctica, Geophys. Res. Lett., 41, 730-735, https://doi.org/10.1002/2013GL058932, 2014. 